\title{
Spectroscopic, Thermal, Electrochemical, and Antimicrobial Studies of Mononuclear Manganese(II) Ditolyldithiophosphates
}

\author{
Ruchi Khajuria, Atiya Syed, Sandeep Kumar, and Sushil K. Pandey \\ Department of Chemistry, University of Jammu, Baba Saheb Ambedkar Road, Jammu and Kashmir 180 006, India \\ Correspondence should be addressed to Sushil K. Pandey; kpsushil@rediffmail.com
}

Received 29 April 2013; Accepted 19 June 2013

Academic Editor: Imre Sovago

Copyright ( 2013 Ruchi Khajuria et al. This is an open access article distributed under the Creative Commons Attribution License, which permits unrestricted use, distribution, and reproduction in any medium, provided the original work is properly cited.

\begin{abstract}
New complexes of manganese(II) corresponding to $\left[\left\{(\mathrm{ArO})_{2} \mathrm{PS}_{2}\right\}_{2} \mathrm{Mn}\right]$ and $\left[\left\{(\mathrm{ArO})_{2} \mathrm{PS}_{2}\right\}_{2} \mathrm{Mn} \cdot \mathrm{nL}\right]\left(\mathrm{Ar}=o-, m-, p-\mathrm{CH}_{3} \mathrm{C}_{6} \mathrm{H}_{4}\right.$ and $p$-Cl- $\left.m-\mathrm{CH}_{3} \mathrm{C}_{6} \mathrm{H}_{3} ; n=1, \mathrm{~L}=\mathrm{N}_{2} \mathrm{C}_{12} \mathrm{H}_{8}, \mathrm{~N}_{2} \mathrm{C}_{10} \mathrm{H}_{8} ; n=2, \mathrm{~L}=\mathrm{NC}_{5} \mathrm{H}_{5}, \mathrm{P}\left(\mathrm{C}_{6} \mathrm{H}_{5}\right)_{3}\right)$ have been synthesized and characterized by microelemental analyses $(\mathrm{C}, \mathrm{H}$, and $\mathrm{N})$, magnetic susceptibility, molar conductance, thermogravimetric, cyclic voltammetry, and spectral analyses including ESI mass spectrometry, IR, and UV-visible. The presence of a four-and-six coordinated Mn atoms has been established in the complexes and adducts, respectively. Antimicrobial screening of the complexes against gram negative bacteria E. coli, K. pneumonia, and P. aeruginosa and fungus $S$. rolfsii has shown potential bioactivity.
\end{abstract}

\section{Introduction}

Manganese has attracted the attention of several researchers owing to the fascinating physical and biochemical characteristics. The utility of manganese is quite diversified such as an alloying agent for aluminium, in dry cell batteries (carbon-zinc Leclanche type), oxidizing agent, and so forth [1]. In nature, manganese is present at the active site of a wide range of enzymes such as catalase and ribonucleotide reductase and participates in a variety of biological reactions [2]. Manganese(II) in its coordination compounds exhibits marked preference for hard donor atoms such as oxygen and nitrogen. Manganese(II) complexes containing soft donor atoms are scanty in number as compared with those of other transition metals, presumably due to difficulties encountered in preparing and preserving such complexes [3]. The first evidence for manganese binding to sulfur donor group in metalloprotein is tryptophanmodified Mn(III) containing acid phosphatise [4]. As compared to the other transition metals, manganese forms complexes with 1,1-dithio and 1,2-dithiolene ligands such as $\left[\mathrm{Mn}(\mathrm{SPh})_{4}\right]^{2-},\left[\mathrm{MnCl}(\mathrm{SPh})_{3}\right]^{2-},\left[\mathrm{Mn}_{4}(\mathrm{SPh})_{10}\right]^{2-},[\mathrm{Mn}$ $\left.(\text { edt })_{2}\right]^{2-},\left[\mathrm{Mn}_{2}(\text { edt })_{4}\right]^{2-}$ (edt $=$ ethane-1,2-dithiolate), and $\left[\mathrm{Mn}_{2}\left(\mathrm{~S}_{2}-\mathrm{O}-\mathrm{xyl}\right)_{2} \mathrm{X}_{2}\right]^{2-}\left(\mathrm{X}=\mathrm{PhS}^{-}, \mathrm{Et}_{2} \mathrm{NCS}_{2}^{-} ; \mathrm{X}_{2}=\mathrm{S}_{2}-\mathrm{O}-\mathrm{xyl}^{2-}\right)$ [5].
The high efficacy of the ligands containing sulfur atoms has been well established in metal chelation therapy and has high potency as fungicides and pesticides [6]. Among sulfur donor ligands, $O, O^{\prime}$-dialkyl and alkylene dithiophosphates have been used for producing potential coordination compounds with most of the metals [7-10]. These soft donor ligands are versatile ligands which show both monodentate [11, 12] and bidentate [13-18] behaviour and form complexes with various metal ions, mainly transition metals [16-18]. Various dithiophosphate derivatives find extensive applications in agriculture [19], industries [20, 21], analytical studies [22], and tribology [23-25]. The versatility of applications of dithiophosphates and their ability to combine with metal ions into a variety of coordination complexes have led to a large interest in their structure and the factors governing the properties of dithiophosphate complexes. The best known complexes of manganese with sulfur ligands are dithiophosphinates $[26,27]$ and the dithiocarbamates [28]. A perusal of the literature reveals no report on the manganese(II) ditolyldithiophosphates. In continuation of our earlier work on ditolyldithiophosphates derivatives, we report in this paper the synthesis and characterization of manganese(II) ditolyldithiophosphates and their adducts with nitrogen and phosphorus donor bases like 1,10-phenanthroline, $\mathrm{N}_{2} \mathrm{C}_{12} \mathrm{H}_{8}, 2,2^{\prime}$-bipyridyl, $\mathrm{N}_{2} \mathrm{C}_{10} \mathrm{H}_{8}$, 
pyridine, $\mathrm{NC}_{5} \mathrm{H}_{5}$, and triphenylphosphine, $\mathrm{P}\left(\mathrm{C}_{6} \mathrm{H}_{5}\right)_{3}$. The electrochemistry of manganese complexes has also been investigated. The complexes were also screened for their antimicrobial activities against some bacteria and fungus.

\section{Experimental}

2.1. Materials and Methods. Stringent precautions were taken to exclude moisture. Moisture was carefully excluded throughout the experimental manipulations by using standard Schlenk techniques. Ortho-, meta-, and parahydroxytoluene (cresols) were distilled before use. Manganese dichloride tetrahydrate (Thomas baker) was used as received. Sodium salts of $O, O^{\prime}-(o-, m-, p$ - and $p$-Cl- $m$-ditolyl)dithiophosphoric acids were prepared by the literature method [29]. The solvents used, benzene, acetone, dichloromethane, hexane, and ethanol were purified and dried by standard methods before use.

2.2. Physical Measurements. Chlorine was estimated volumetrically by Volhard's method [30]. Manganese was estimated gravimetrically as $\mathrm{Mn}_{2} \mathrm{P}_{2} \mathrm{O}_{7}$ [30]. IR spectra were recorded in $\mathrm{KBr}$ pellets in the range of $4000-200 \mathrm{~cm}^{-1}$ with a Perkin Elmer-spectrum RX1 FT-IR spectrophotometer and Shimadzu FT-IR-8400S. The electronic spectra of the complexes were recorded in a range of $200-800 \mathrm{~nm}$ on a T90 + UV/VIS spectrophotometer using a pair of matched quartz cells of $10 \mathrm{~mm}$ path length at an ambient temperature. The mass spectra were recorded on VG-70-S mass spectrophotometer. The room temperature magnetic susceptibility measurements have been carried out by vibrating sample magnetometer (VSM). Molar conductance of the complexes was determined by using digital conductivity meter Century CC 601. The thermograms were analyzed by using Perkin Elmer, diamond TG/DTA instrument. Recrystallized alumina sample holder was used with the heating rate of $20^{\circ} \mathrm{C}$ per minute. The thermograms were recorded in the temperature range from $30^{\circ} \mathrm{C}$ to $1000^{\circ} \mathrm{C}$. The experiment was carried out under a flow rate of $50 \mathrm{~mL}$ per minute of nitrogen atmosphere. The cyclic voltammograms were recorded on Autolab. The potential is applied between the reference electrode $(\mathrm{Ag} / \mathrm{AgCl})$ and the working electrode (Gold electrode), and the current is measured between the working electrode and the counter electrode (platinum wire). For all the measurements, $0.1 \mathrm{M}$ phosphate buffer solution $(\mathrm{pH}=7)$ was used. Elemental analyses $(\mathrm{C}, \mathrm{H}$, and $\mathrm{N})$ were carried out on Vario EL III and CHNS-932 Leco Elemental analyser; their results were found to be in good agreement $( \pm 0.3 \%)$ with the calculated values.

2.3. Synthesis of $\left[\left\{\left(\mathrm{o}-\mathrm{CH}_{3} \mathrm{C}_{6} \mathrm{H}_{4} \mathrm{O}\right)_{2} \mathrm{PS}_{2}\right\}_{2} \mathrm{Mn}\right]$ (1). An Acetone solution $(30 \mathrm{~mL})$ of $\mathrm{MnCl}_{2} .4 \mathrm{H}_{2} \mathrm{O}(0.30 \mathrm{~g}, 1.51 \mathrm{mmol})$ was added dropwise to acetone solution of $\left(o-\mathrm{CH}_{3} \mathrm{C}_{6} \mathrm{H}_{4} \mathrm{O}\right)_{2}$ $\mathrm{PS}_{2} \mathrm{Na}(1.00 \mathrm{~g}, 3.00 \mathrm{mmol})$ with constant stirring and then refluxed for $4 \mathrm{~h}$. The color of contents changed to colorless with the precipitation of sodium chloride. The precipitates of sodium chloride were filtered off by using a funnel fitted with G-4 disc. Excess of solvent from the filtrate was evaporated in vacuo which resulted in the formation of the complex $[\{(o-$ $\left.\left.\mathrm{CH}_{3} \mathrm{C}_{6} \mathrm{H}_{4} \mathrm{O}\right)_{2} \mathrm{PS}_{2}\right\}_{2} \mathrm{Mn}$ ] (1) as white solid in $95 \%$ yield. The complexes 2-4 were prepared by similar procedure.

2.4. Synthesis of $\left[\left\{\left(\mathrm{o}-\mathrm{CH}_{3} \mathrm{C}_{6} \mathrm{H}_{4} \mathrm{O}\right)_{2} \mathrm{PS}_{2}\right\}_{2} \mathrm{Mn} \cdot \mathrm{N}_{2} \mathrm{C}_{12} \mathrm{H}_{8}\right]$ (5). A mixture of $\mathrm{MnCl}_{2} .4 \mathrm{H}_{2} \mathrm{O}(0.30 \mathrm{~g}, 1.51 \mathrm{mmol})$ and $\mathrm{N}_{2} \mathrm{C}_{12} \mathrm{H}_{8}$ $(0.27 \mathrm{~g}, 1.49 \mathrm{mmol})$ in water-ethanol medium $(30 \mathrm{~mL})$ was added to the aqueous solution of $\left(o-\mathrm{CH}_{3} \mathrm{C}_{6} \mathrm{H}_{4} \mathrm{O}\right)_{2} \mathrm{PS}_{2} \mathrm{Na}$ $(1.00 \mathrm{~g}, 3.01 \mathrm{mmol})$ in a dropwise manner through a dropping funnel. Immediately, the yellow colored precipitates were formed which were separated by filteration using funnel fitted with $\mathrm{G}-4$ disc. The product $\left[\left\{\left(o-\mathrm{CH}_{3} \mathrm{C}_{6} \mathrm{H}_{4} \mathrm{O}\right)_{2}\right.\right.$ $\left.\mathrm{PS}_{2}\right\}_{2} \mathrm{Mn} \cdot \mathrm{N}_{2} \mathrm{C}_{12} \mathrm{H}_{8}$ ] (5) was obtained as yellow solid in $94 \%$ yield. Adducts numbered 6-16 were isolated by similar route.

2.5. Synthesis of $\left[\left\{\left(\mathrm{o}-\mathrm{CH}_{3} \mathrm{C}_{6} \mathrm{H}_{4} \mathrm{O}\right)_{2} \mathrm{PS}_{2}\right\}_{2} \mathrm{Mn} \cdot 2 \mathrm{P}\left(\mathrm{C}_{6} \mathrm{H}_{5}\right)_{3}\right]$ (17). Acetone solution $(30 \mathrm{~mL})$ of $\left(o-\mathrm{CH}_{3} \mathrm{C}_{6} \mathrm{H}_{4} \mathrm{O}\right)_{2} \mathrm{PS}_{2} \mathrm{Na}(1.00 \mathrm{~g}$, $3.01 \mathrm{mmol})$ was added to a acetone solution $(10 \mathrm{~mL})$ of $\mathrm{MnCl}_{2} .4 \mathrm{H}_{2} \mathrm{O}(0.30 \mathrm{~g}, 1.50 \mathrm{mmol})$ with constant stirring at room temperature followed by the addition of the solution of $\mathrm{P}\left(\mathrm{C}_{6} \mathrm{H}_{5}\right)_{3}(0.79 \mathrm{~g}, 3.01 \mathrm{mmol})$ in acetone $(10 \mathrm{~mL})$. The reaction mixture was refluxed for $4 \mathrm{~h}$. The precipitated sodium chloride was removed by filtration using a funnel fitted with G-4 disc. The desired product $[\{(o-$ $\left.\left.\left.\mathrm{CH}_{3} \mathrm{C}_{6} \mathrm{H}_{4} \mathrm{O}\right)_{2} \mathrm{PS}_{2}\right\}_{2} \mathrm{Mn} \cdot 2 \mathrm{P}\left(\mathrm{C}_{6} \mathrm{H}_{5}\right)_{3}\right]$ (17) was obtained in $90 \%$ yield as white solid. Complexes numbered 18-20 were prepared by this method.

\subsection{Biological Activity}

2.6.1. Antibacterial. Test samples were prepared in different concentrations (100, 150, 200, and $250 \mathrm{ppm})$ in DMSO. Agar medium $(20 \mathrm{~mL})$ was poured into each petri plate and left to solidify. The plates were then swabbed with broth cultures of the respective microorganisms (E. coli, K. pneumonia, and $P$. aeruginosa) and kept for $15 \mathrm{~min}$ for adsorption to take place. Using a punch, $\approx 6 \mathrm{~mm}$ diameter, wells were bored in the seeded agar plates and $100 \mu \mathrm{L}$ of the DMSO solution of each test compound was added into the wells. DMSO was used as the control for all the test compounds as it exhibited no effect on the organism tested, and Ciprofloxacin was used as the standard drug. After holding the plates at room temperature for $2 \mathrm{~h}$ to allow diffusion of the compounds into the agar, the plates were incubated at $37^{\circ} \mathrm{C}$ for $24 \mathrm{~h}$. The antibacterial activity was determined by measuring the diameter of the inhibition zone. The entire tests were made in triplicates, and the mean of the diameter of zone of inhibition was calculated.

2.6.2. Antifungal. Potato dextrose medium (PDA) was prepared in a flask and sterilized. $100 \mu \mathrm{L}$ of each sample was added to the PDA medium and poured into each sterilized Petri plate. Mycelial discs taken from the standard culture ( $S$. rolfsii) of fungi were grown on PDA medium for 7 days. These cultures were used for aseptic inoculation in the sterilized Petri dish. Standard cultures, inoculated at $28 \pm 1^{\circ} \mathrm{C}$, were used as control. The efficacy of each sample was determined by measuring the radial fungal growth. The radial growth of the colony was measured in two directions at right angle to 
each other, and the average of two replicates was recorded in each case. Data were expressed as percent inhibition over the control from the size of the colonies. The percent inhibition was calculated using the formulae: \% inhibition $=((C-T) / C) \times 100$, where $C$ is the diameter of the fungus colony in the control plate after $96 \mathrm{~h}$ incubation and $T$ is the diameter of the fungus colony in the tested plate after the same incubation period. Both antibacterial and antifungal activities were tested in the Bio-assay lab, Department of Chemistry, University of Jammu, Jammu.

\section{Results and Discussion}

The reactions of manganese dichloride (tetrahydrate) with sodium salt of $O, O^{\prime}-(o-, m-, p$ - and $p$-Cl- $m$-ditolyl)dithiophosphates in refluxed acetone with constant stirring in $1: 2$ molar stoichiometry yielded the complexes corresponding to $\left[\left\{(\mathrm{ArO})_{2} \mathrm{PS}_{2}\right\}_{2} \mathrm{Mn}\right](\mathbf{1 - 4})\left(\mathrm{Ar}=o-, \quad m-, p-\mathrm{CH}_{3} \mathrm{C}_{6} \mathrm{H}_{4}\right.$ and $\left.p-\mathrm{Cl}-m-\mathrm{CH}_{3} \mathrm{C}_{6} \mathrm{H}_{3}\right)$. The adducts were prepared by the reaction $\mathrm{MnCl}_{2} \cdot 4 \mathrm{H}_{2} \mathrm{O},\left[\left(o-, m-, p-\mathrm{CH}_{3} \mathrm{C}_{6} \mathrm{H}_{4} \mathrm{O}\right.\right.$ or $p-\mathrm{Cl}-m$ $\left.\mathrm{CH}_{3} \mathrm{C}_{6} \mathrm{H}_{3} \mathrm{O}\right)_{2} \mathrm{PS}_{2} \mathrm{Na}$ ] and donor base in $1: 2: 1$ and $1: 2: 2$ molar stoichiometry for bidentate $\left(\mathrm{N}_{2} \mathrm{C}_{12} \mathrm{H}_{8}\right.$ (5-8) and $\mathrm{N}_{2} \mathrm{C}_{10} \mathrm{H}_{8}$ (9-12)) and monodentate donor ligand, $\left(\mathrm{NC}_{5} \mathrm{H}_{5}\right.$ (13-16) and $\mathrm{P}_{6}\left(\mathrm{C}_{6} \mathrm{H}_{5}\right)_{3}$ (17-20)), respectively (Scheme 1). It is pertinent to mention that adducts of manganese ditolyldithiophosphates with nitrogen donors were prepared in water-ethanol medium, while adducts with triphenylphosphine were prepared in acetone. This choice of solvent medium was made on the basis of better solvation of triphenylphosphine in acetone in comparison to water-ethanol medium.

All these complexes are soluble in common organic solvents and insoluble in solvents like n-hexane and carbon tetrachloride. The complexes (1-4) obtained are white solids, whereas adducts with nitrogen donors are yellow (5-16), and that of phosphorus donor are white (17-20) solids. The synthetic and analytical data of the complexes (1-20) are summarized in Table 1.

3.1. IR Spectra. IR spectral assignments of these complexes (1-20) were made on the basis of relevant literature reports $[26-28,31,32]$. The comparison of IR spectra of these complexes with starting materials has also shown significant and characteristic changes and also shifting of bands. Two strong intensity bands were observed in the region 1160.7$1080.0 \mathrm{~cm}^{-1}$ and $960.2-896.8 \mathrm{~cm}^{-1}$, which may be ascribed to the $\nu(\mathrm{P})-\mathrm{O}-\mathrm{C}$ and $\nu \mathrm{P}-\mathrm{O}-(\mathrm{C})$ vibrations, respectively. The bands for $\nu \mathrm{P}=\mathrm{S}$ and $\nu \mathrm{P}-\mathrm{S}$ were observed in the regions $696.2-651.8 \mathrm{~cm}^{-1}$ and $640.3-541.9 \mathrm{~cm}^{-1}$. The bands due to $\nu \mathrm{P}=\mathrm{S}$ and $\nu \mathrm{P}-\mathrm{S}$ vibrations have depicted a shift of $10-$ $30 \mathrm{~cm}^{-1}$ towards the lower frequency region in comparison to the parent dithiophosphate ligands. The observation of two closely spaced bands arising from $v\left(\mathrm{PS}_{2}\right)$ vibrations is entirely typical for bidentate chelating dithiophosphates units. This shift of $\nu \mathrm{P}-\mathrm{S}$ vibrations is, perhaps, due to bidentate mode of bonding by dithiophosphates ligands. The presence of a band in the region $291.0-214.3 \mathrm{~cm}^{-1}$, attributed to $\nu \mathrm{Mn}-\mathrm{S}$, is indicative of the formation of manganese-sulfur bond.
This is supported by the literature survey [26]. Cavell et al. have reported similar structure IR frequency ranges for $\mathrm{Mn}-\mathrm{S}$ bond which is in agreement with our observations. IR spectra have also revealed the presence of bands of $\nu \mathrm{Mn}-\mathrm{N}$ and $\nu \mathrm{Mn}-$ $\mathrm{P}$ in the regions $486.0-422.3 \mathrm{~cm}^{-1}$ and $384.9-360.2 \mathrm{~cm}^{-1}$, respectively $[31,32]$. The relevant IR spectral data of these complexes are given in Table 2.

3.2. Mass Spectra. The mass spectra of a few representative complexes $(1,5,8,9,11,14,16,17$ and 19) have exhibited the presence of molecular ion peak. In addition to the molecular ion peak, several other peaks were also observed, which are corresponding to the fragmented species after the consecutive removal of different groups. The occurrence of molecular ion peak in the complexes is supporting the monomeric nature of the complexes. Furthermore, the adducts ( 8 and $\mathbf{1 6})$ that contain multiple chlorines (i.e., two chlorine atoms) also show isotopic peaks. Based on the presence of the peaks in the mass spectra of some of the representative complexes, the various fragments have been given in Table 3 .

3.3. Electronic Spectra. The intense electronic spectra of the complexes (1-20) show absorption in the ranges of 339$396 \mathrm{~nm}, 431-479 \mathrm{~nm}$, and $510-573 \mathrm{~nm}$, which may be ascribed to ${ }^{6} \mathrm{~A}_{1 \mathrm{~g}} \rightarrow{ }^{4} \mathrm{E}_{\mathrm{g}}\left({ }^{4} \mathrm{D}\right),{ }^{6} \mathrm{~A}_{1 \mathrm{~g}} \rightarrow{ }^{4} \mathrm{E}_{\mathrm{g}}\left({ }^{4} \mathrm{G}\right)$ and ${ }^{6} \mathrm{~A}_{1 \mathrm{~g}} \rightarrow{ }^{4} \mathrm{~T}_{1 \mathrm{~g}}$ $\left({ }^{4} \mathrm{G}\right)$ and are assigned to $d$ - $d$ transition [33]. The transition in these complexes indicated that the manganese is $d^{5}$ with the ground term ${ }^{6} S$ which do not split and transformed to the ${ }^{6} \mathrm{~A}_{1 \mathrm{~g}}$ state. The transition in these complexes is both spin forbidden and orbital forbidden, due to this, the absorption bands are extremely weak. Other weak intensity absorption bands in the region 247-296 nm are observed in adducts (520) which may be ascribed to the transition between the metal to ligand $(\mathrm{M} \rightarrow \mathrm{L})$ charge transfer spectra [34]. This signifies that there is another moiety present in these adducts that is, donor atoms of 1,10-phenanthroline, 2,2' -bipyridyl, pyridine, and triphenylphosphine. The tentative assignments of the important bands for the complexes (1-4) and adducts (5-20) have been made and summarized in Table 4 .

3.4. Magnetic Susceptibility. As a consequence of the weak field nature of the dithiophosphate ligand, effective magnetic moment values $\left(\mu_{\text {eff }}\right)$ of all the manganese(II) complexes are high and appear in the range of 5.60-5.90 B.M. Magnetic susceptibility measurements show that these complexes are paramagnetic $[26,27]$. The relevant magnetic moment values of these complexes are tabulated in Table 4 .

3.5. Molar Conductance. The mononuclear complexes are dissolved in DMSO, and the molar conductance of $10^{-3} \mathrm{M}$ solutions at $30^{\circ} \mathrm{C}$ was measured. It is concluded from the results that the complexes have a molar conductance in the range of $4.36-9.81 \Omega^{-1} \mathrm{~cm}^{2} \mathrm{~mol}^{-1}$, which indicates the nonionic nature of these complexes [6]. Hence, these complexes have nonelectrolytic properties in DMSO. The molar conductance value of the complexes is given in Table 1. 


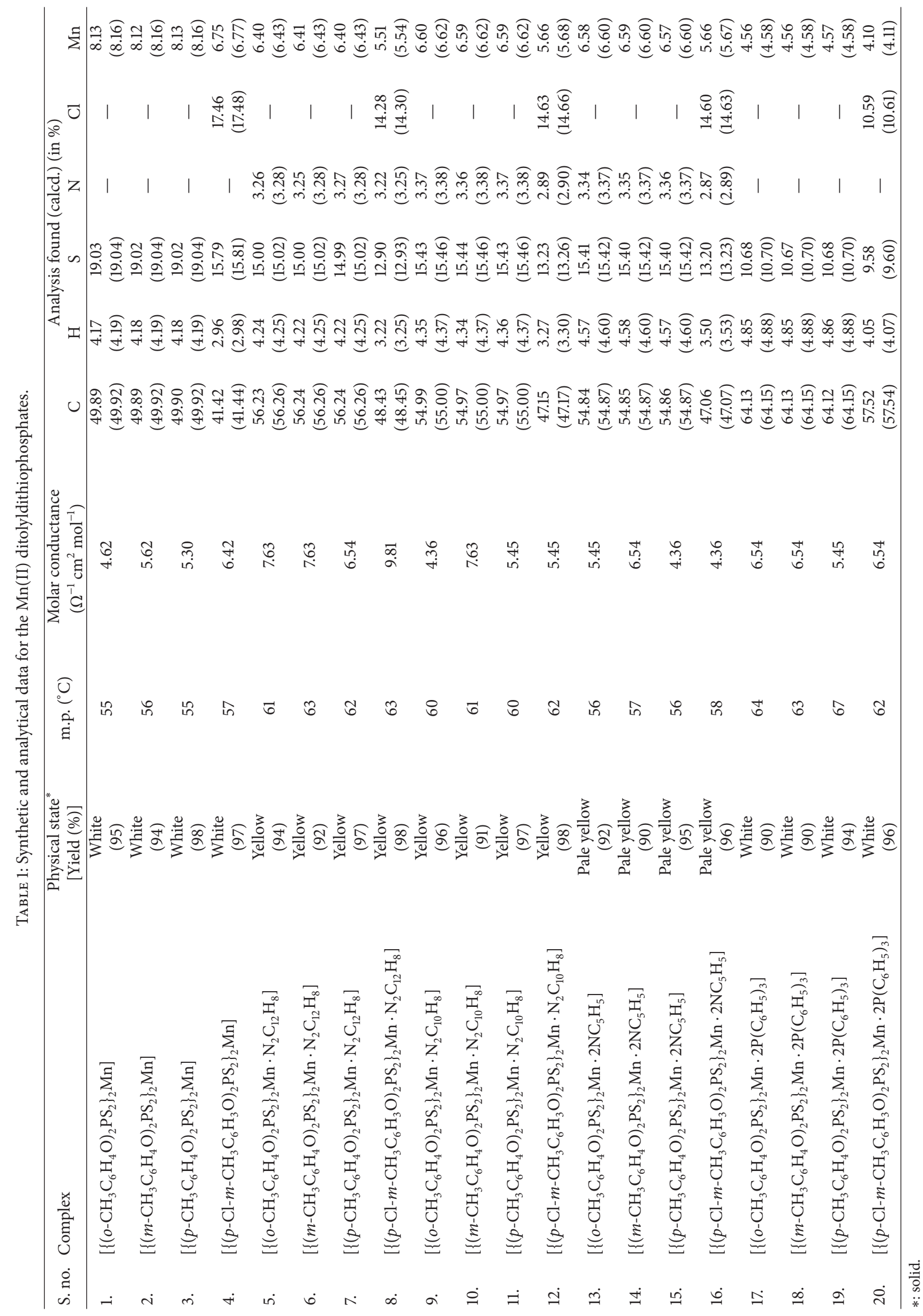






Scheme 1: Reactions showing synthesis of $O, O^{\prime}-(o-, m-, p$ - and $p$-Cl- $m$-ditolyl) dithiophosphato complexes of Mn(II) and their adducts with nitrogen and phosphorus donor ligands.

TABLE 2: IR spectral data for Mn(II) ditolyldithiophosphates $\left(\mathrm{cm}^{-1}\right)$.

\begin{tabular}{|c|c|c|c|c|c|c|c|}
\hline S. no. & $v(\mathrm{P})-\mathrm{O}-\mathrm{C}$ & $v \mathrm{P}-\mathrm{O}-(\mathrm{C})$ & $v \mathrm{P}=\mathrm{S}$ & $v \mathrm{P}-\mathrm{S}$ & $v \mathrm{Mn}-\mathrm{S}$ & $v \mathrm{Mn}-\mathrm{P}$ & $v \mathrm{Mn}-\mathrm{N}$ \\
\hline 1. & $1159.2, \mathrm{~s}$ & $923.4, \mathrm{~s}$ & $686.3, \mathrm{~s}$ & $546.8, \mathrm{~m}$ & $235.6, \mathrm{w}$ & - & - \\
\hline 2. & 1109.1, s & $919.2, \mathrm{~s}$ & $686.4, \mathrm{~s}$ & $581.4, \mathrm{~m}$ & $249.5, \mathrm{w}$ & - & - \\
\hline 3. & $1103.2, \mathrm{~s}$ & 925.7, s & $696.0, \mathrm{~s}$ & $561.7, \mathrm{~m}$ & $247.3, \mathrm{w}$ & - & - \\
\hline 4. & $1140.3, \mathrm{~s}$ & 957.0, s & $684.8, \mathrm{~s}$ & $607.6, \mathrm{~m}$ & $246.8, \mathrm{w}$ & - & - \\
\hline 5. & 1143.7, s & 900.7, s & $682.7, \mathrm{~s}$ & $551.6, \mathrm{~m}$ & $252.4, \mathrm{w}$ & - & $445.5, \mathrm{w}$ \\
\hline 6. & $1121.4, \mathrm{~s}$ & 903.6, s & $675.2, \mathrm{~s}$ & $586.4, \mathrm{~m}$ & $273.6, \mathrm{w}$ & - & 453.6, w \\
\hline 7. & 1112.7, s & $898.7, \mathrm{~s}$ & $692.4, \mathrm{~s}$ & $565.4, \mathrm{~m}$ & $254.9, \mathrm{w}$ & - & $476.3, \mathrm{w}$ \\
\hline 8. & $1149.5, \mathrm{~s}$ & 954.7, s & $688.5, \mathrm{~s}$ & $640.3, \mathrm{~m}$ & $263.4, \mathrm{w}$ & - & $445.5, \mathrm{w}$ \\
\hline 9. & 1157.1, s & $906.4, \mathrm{~s}$ & $669.2, \mathrm{~s}$ & $552.4, \mathrm{~m}$ & $273.4, \mathrm{w}$ & - & 472.6, w \\
\hline 10. & $1110.9, \mathrm{~s}$ & $900.3, \mathrm{~s}$ & 671.1, s & $566.4, \mathrm{~m}$ & $261.2, \mathrm{w}$ & - & $428.1, \mathrm{w}$ \\
\hline 11. & $1101.2, \mathrm{~s}$ & $896.8, \mathrm{~s}$ & $694.3, \mathrm{~s}$ & $560.1, \mathrm{~m}$ & $254.9, \mathrm{w}$ & - & 464.8, w \\
\hline 12. & $1151.4, \mathrm{~s}$ & 954.7, s & $651.8, \mathrm{~s}$ & $609.4, \mathrm{~m}$ & $255.7, \mathrm{w}$ & - & 484.1, w \\
\hline 13. & $1108.9, \mathrm{~s}$ & $910.3, \mathrm{~s}$ & 671.1, s & $559.3, \mathrm{~m}$ & 232.7, w & - & 441.6, w \\
\hline 14. & $1080.0, \mathrm{~s}$ & $919.9, \mathrm{~s}$ & $696.2, \mathrm{~s}$ & $590.1, \mathrm{~m}$ & 245.7, w & - & $486.0, \mathrm{w}$ \\
\hline 15. & 1103.2, s & $910.3, \mathrm{~s}$ & $694.3, \mathrm{~s}$ & $592.4, \mathrm{~m}$ & $250.0, \mathrm{w}$ & - & $422.3, \mathrm{w}$ \\
\hline 16. & $1159.3, \mathrm{~s}$ & $960.2, \mathrm{~s}$ & 683.6, s & $601.3, \mathrm{~m}$ & $246.3, \mathrm{w}$ & - & $442.6, \mathrm{w}$ \\
\hline 17. & 1105.1, s & $908.4, \mathrm{~s}$ & 673.7, s & 541.9, m & $214.3, \mathrm{w}$ & $384.9, \mathrm{w}$ & - \\
\hline 18. & $1103.2, \mathrm{~s}$ & $925.4, \mathrm{~s}$ & $692.4, \mathrm{~s}$ & $587.6, \mathrm{~m}$ & $242.4, \mathrm{w}$ & $379.4, \mathrm{w}$ & - \\
\hline 19. & $1123.2, \mathrm{~s}$ & $902.6, \mathrm{~s}$ & $692.4, \mathrm{~s}$ & $557.4, \mathrm{~m}$ & 291.0, w & $361.1, \mathrm{w}$ & - \\
\hline 20. & $1160.7, \mathrm{~s}$ & $957.4, \mathrm{~s}$ & $680.1, \mathrm{~s}$ & $603.5, \mathrm{~m}$ & $282.4, \mathrm{w}$ & $360.2, \mathrm{w}$ & - \\
\hline
\end{tabular}

s: strong; m: medium; w: weak.

3.6. Thermogravimetric Analysis. The thermal behaviour of the complex $\left[\left\{\left(o-\mathrm{CH}_{3} \mathrm{C}_{6} \mathrm{H}_{4} \mathrm{O}\right)_{2} \mathrm{PS}_{2}\right\}_{2} \mathrm{Mn}\right]$ (1) displayed a thermolysis step that covers a temperature range from 150 to $986^{\circ} \mathrm{C}$. The main weight loss occurs in the steeply descending segment of the TG curve (Figure 1); the DTG curve shows the increasing rate of the weight loss up to $986.71^{\circ} \mathrm{C}$. This weight loss of $58.58 \%$ at $151.7^{\circ} \mathrm{C}$ is due to the formation of bis(dithiometaphosphato ) manganese(II) $\left[\mathrm{Mn}\left(\mathrm{S}_{2} \mathrm{PO}\right)_{2}\right]$, (the calculated weight loss is $58.86 \%$ ) as an intermediate product, which agrees with thermogravimetric data for dithiophosphates. The weight of the final residue is $21.38 \%$ of the initial weight of the sample; this corresponds to the formation of $\mathrm{MnSO}_{4}$ contaminated with other thermolysis products (the calculated value is $22.42 \%$ ) at $986.71^{\circ} \mathrm{C}$. The thermogravimetric analysis of the adduct $\left[\left\{\left(o-\mathrm{CH}_{3} \mathrm{C}_{6} \mathrm{H}_{4} \mathrm{O}\right)_{2} \mathrm{PS}_{2}\right\}_{2} \mathrm{Mn} \cdot \mathrm{N}_{2} \mathrm{C}_{12} \mathrm{H}_{8}\right]$ (5) (Figure 2) exhibited loss of the donor ligand resulting in the formation of the intermediate compound $\left[\left\{\left(o-\mathrm{CH}_{3} \mathrm{C}_{6} \mathrm{H}_{4} \mathrm{O}\right)_{2} \mathrm{PS}_{2}\right\}_{2} \mathrm{Mn}\right]$ (the calculated weight loss is $21.85 \%$ ) at $68.99^{\circ} \mathrm{C}$. The rate of the weight loss begins to increase steeply at $303.92^{\circ} \mathrm{C}$. The weight loss at this point is due to the formation of $\left[\mathrm{Mn}\left(\mathrm{S}_{2} \mathrm{PO}\right)_{2}\right]$ (the calculated weight loss is $67.85 \%$ ). The weight of the final 
TABLE 3: Mass spectral data of the Mn(II) ditolyldithiophosphates.

\begin{tabular}{|c|c|c|}
\hline S. no. & M. Wt. & $m / z$, relative intensities of the ions and assignment \\
\hline 1. & 673.6 & $\begin{array}{l}{\left[\mathrm{M}^{+}\right] 673.6(10)\left[\left\{\left(o-\mathrm{CH}_{3} \mathrm{C}_{6} \mathrm{H}_{4} \mathrm{O}\right)_{2} \mathrm{PS}_{2}\right\}_{2} \mathrm{Mn}\right]^{+}} \\
{\left[\mathrm{M}^{+}\right] 364.3(14)\left[\left\{\left(o-\mathrm{CH}_{3} \mathrm{C}_{6} \mathrm{H}_{4} \mathrm{O}\right)_{2} \mathrm{PS}_{2}\right\} \mathrm{Mn}\right]^{+}} \\
{\left[\mathrm{M}^{+}\right] 277.1(45)\left[\mathrm{Mn}\left(\mathrm{S}_{2} \mathrm{PO}\right)_{2}\right]^{+}} \\
{\left[\mathrm{M}^{+}\right] 107.1(59)\left[o-\mathrm{CH}_{3} \mathrm{C}_{6} \mathrm{H}_{4} \mathrm{O}\right]^{-}}\end{array}$ \\
\hline 5. & 853.8 & $\begin{array}{l}{\left[\mathrm{M}^{+}\right] 853.8(12)\left[\left\{\left(p-\mathrm{CH}_{3} \mathrm{C}_{6} \mathrm{H}_{4} \mathrm{O}\right)_{2} \mathrm{PS}_{2}\right\}_{2} \mathrm{Mn} \cdot \mathrm{C}_{12} \mathrm{H}_{8} \mathrm{~N}_{2}\right]^{+} ;} \\
{\left[\mathrm{M}^{+}\right] 544.5(18)\left[\left\{\left(p-\mathrm{CH}_{3} \mathrm{C}_{6} \mathrm{H}_{4} \mathrm{O}\right)_{2} \mathrm{PS}_{2}\right\} \mathrm{Mn} \cdot \mathrm{C}_{12} \mathrm{H}_{8} \mathrm{~N}_{2}\right]^{+} ;} \\
{\left[\mathrm{M}^{+}\right] 309.3(56)\left[\left(p-\mathrm{CH}_{3} \mathrm{C}_{6} \mathrm{H}_{4} \mathrm{O}\right)_{2} \mathrm{PS}_{2}\right]^{-}} \\
{\left[\mathrm{M}^{+}\right] 218.2(67)\left[\left(p-\mathrm{CH}_{3} \mathrm{C}_{6} \mathrm{H}_{4} \mathrm{O}\right) \mathrm{P}(\mathrm{O}) \mathrm{S}_{2}\right]^{-} ;} \\
{\left[\mathrm{M}^{+}\right] 107.1(70)\left[p-\mathrm{CH}_{3} \mathrm{C}_{6} \mathrm{H}_{4} \mathrm{O}\right]^{-}}\end{array}$ \\
\hline 8. & 991.6 & $\begin{array}{l}{\left[\mathrm{M}^{+}\right]^{\dagger} 991.6(15), 993.6(9), 995.6(5)\left[\left\{\left(p-\mathrm{Cl}-m-\mathrm{CH}_{3} \mathrm{C}_{6} \mathrm{H}_{3} \mathrm{O}\right)_{2} \mathrm{PS}_{2}\right\}_{2} \mathrm{Mn} \cdot \mathrm{C}_{12} \mathrm{H}_{8} \mathrm{~N}_{2}\right]^{+}} \\
{\left[\mathrm{M}^{+}\right]^{\dagger} 788.4(17), 790.4(11), 792.4(9)\left[\left\{\left(p-\mathrm{Cl}-m-\mathrm{CH}_{3} \mathrm{C}_{6} \mathrm{H}_{3} \mathrm{O}\right)_{2} \mathrm{PS}_{2}\right\} \mathrm{Mn} \cdot \mathrm{C}_{12} \mathrm{H}_{8} \mathrm{~N}_{2}\right]^{+} ;} \\
{\left[\mathrm{M}^{+}\right]^{\dagger} 433.1(21), 433.3(14), 433.5(10)\left[\left\{\left(p-\mathrm{Cl}-m-\mathrm{CH}_{3} \mathrm{C}_{6} \mathrm{H}_{3} \mathrm{O}\right)_{2} \mathrm{PS}_{2}\right\} \mathrm{Mn}\right]} \\
{\left[\mathrm{M}^{+}\right] 277.2(48)\left[\left(\mathrm{C}_{6} \mathrm{H}_{3} \mathrm{O}\right){ }_{2} \mathrm{PS}_{2}\right]^{-} ;} \\
{\left[\mathrm{M}^{+}\right] 201.2(56)\left[m-\mathrm{CH}_{3} \mathrm{C}_{6} \mathrm{H}_{3} \mathrm{OPS}\right]^{-} ;} \\
{\left[\mathrm{M}^{+}\right]^{\dagger} 141.5(60), 143.5(32), 145.5(17)\left[p-\mathrm{Cl}-m-\mathrm{CH}_{3} \mathrm{C}_{6} \mathrm{H}_{3} \mathrm{O}\right]^{-} ;}\end{array}$ \\
\hline 9. & 829.8 & $\begin{array}{l}{\left[\mathrm{M}^{+}\right] 829.8(7)\left[\left\{\left(o-\mathrm{CH}_{3} \mathrm{C}_{6} \mathrm{H}_{4} \mathrm{O}\right)_{2} \mathrm{PS}_{2}\right\}_{2} \mathrm{Mn} \cdot \mathrm{C}_{10} \mathrm{H}_{8} \mathrm{~N}_{2}\right]^{+} ;} \\
{\left[\mathrm{M}^{+}\right] 520.4(98)\left[\left\{\left(o-\mathrm{CH}_{3} \mathrm{C}_{6} \mathrm{H}_{4} \mathrm{O}\right)_{2} \mathrm{PS}_{2}\right\} \mathrm{Mn} \cdot \mathrm{C}_{10} \mathrm{H}_{8} \mathrm{~N}_{2}\right]^{+} ;} \\
{\left[\mathrm{M}^{+}\right] 364.3(14)\left[\left\{\left(o-\mathrm{CH}_{3} \mathrm{C}_{6} \mathrm{H}_{4} \mathrm{O}\right)_{2} \mathrm{PS}_{2}\right\} \mathrm{Mn}\right]^{+} ;} \\
{\left[\mathrm{M}^{+}\right] 277.1(7)\left[\mathrm{Mn}\left(\mathrm{S}_{2} \mathrm{PO}\right)_{2}\right]^{+} ;} \\
{\left[\mathrm{M}^{+}\right] 107.1(20)\left[o-\mathrm{CH}_{3} \mathrm{C}_{6} \mathrm{H}_{4} \mathrm{O}\right]^{-} ;}\end{array}$ \\
\hline 11. & 829.8 & $\begin{array}{l}{\left[\mathrm{M}^{+}\right] 829.8(8)\left[\left\{\left(p-\mathrm{CH}_{3} \mathrm{C}_{6} \mathrm{H}_{4} \mathrm{O}\right)_{2} \mathrm{PS}_{2}\right\}_{2} \mathrm{Mn} \cdot \mathrm{C}_{10} \mathrm{H}_{8} \mathrm{~N}_{2}\right]^{+} ;} \\
{\left[\mathrm{M}^{+}\right] 520.4(98)\left[\left\{\left(p-\mathrm{CH}_{3} \mathrm{C}_{6} \mathrm{H}_{4} \mathrm{O}\right)_{2} \mathrm{PS}_{2}\right\} \mathrm{Mn} \cdot \mathrm{C}_{10} \mathrm{H}_{8} \mathrm{~N}_{2}\right]^{+} ;} \\
{\left[\mathrm{M}^{+}\right] 364.3(14)\left[\left\{\left(p-\mathrm{CH}_{3} \mathrm{C}_{6} \mathrm{H}_{4} \mathrm{O}\right)_{2} \mathrm{PS}_{2}\right\} \mathrm{Mn}\right]^{+} ;} \\
{\left[\mathrm{M}^{+}\right] 277.1(7)\left[\mathrm{Mn}\left(\mathrm{S}_{2} \mathrm{PO}\right)_{2}\right]^{+} ;} \\
{\left[\mathrm{M}^{+}\right] 107.1(20)\left[p-\mathrm{CH}_{3} \mathrm{C}_{6} \mathrm{H}_{4} \mathrm{O}\right]^{-} ;}\end{array}$ \\
\hline 14. & 831.8 & $\begin{array}{l}{\left[\mathrm{M}^{+}\right] 831.8(7)\left[\left\{\left(m-\mathrm{CH}_{3} \mathrm{C}_{6} \mathrm{H}_{4} \mathrm{O}\right)_{2} \mathrm{PS}_{2}\right\}_{2} \mathrm{Mn} \cdot 2 \mathrm{C}_{5} \mathrm{H}_{5} \mathrm{~N}\right]^{+}} \\
{\left[\mathrm{M}^{+}\right] 364.3(98)\left[\left\{\left(m-\mathrm{CH}_{3} \mathrm{C}_{6} \mathrm{H}_{4} \mathrm{O}\right)_{2} \mathrm{PS}_{2}\right\} \mathrm{Mn}\right]^{+}} \\
{\left[\mathrm{M}^{+}\right] 309.3(40)\left[\left(m-\mathrm{CH}_{3} \mathrm{C}_{6} \mathrm{H}_{4} \mathrm{O}\right)_{2} \mathrm{PS}_{2}\right]^{-}} \\
{\left[\mathrm{M}^{+}\right] 202.5(40)\left[m-\mathrm{CH}_{3} \mathrm{C}_{6} \mathrm{H}_{4} \mathrm{OPS}_{2}\right]^{-}} \\
{\left[\mathrm{M}^{+}\right] 277.1(7)\left[\mathrm{Mn}\left(\mathrm{S}_{2} \mathrm{PO}\right)_{2}\right]^{+}} \\
{\left[\mathrm{M}^{+}\right] 107.1(20)\left[m-\mathrm{CH}_{3} \mathrm{C}_{6} \mathrm{H}_{4} \mathrm{O}\right]^{-}}\end{array}$ \\
\hline 16. & 969.6 & $\begin{array}{l}{\left[\mathrm{M}^{+}\right]^{\dagger} 969.6(12) 971.6(8), 973.6(3)\left[\left\{\left(p-\mathrm{Cl}-m-\mathrm{CH}_{3} \mathrm{C}_{6} \mathrm{H}_{3} \mathrm{O}\right)_{2} \mathrm{PS}_{2}\right\}_{2} \mathrm{Mn} \cdot 2 \mathrm{C}_{5} \mathrm{H}_{5} \mathrm{~N}\right]^{+} ;} \\
{\left[\mathrm{M}^{+}\right]^{\dagger} 512.2(18), 514.2(11), 516.2(6)\left[\left(p-\mathrm{Cl}-m-\mathrm{CH}_{3} \mathrm{C}_{6} \mathrm{H}_{3} \mathrm{O}\right)_{2} \mathrm{PS}_{2} \mathrm{Mn} \cdot \mathrm{C}_{5} \mathrm{H}_{5} \mathrm{~N}\right]^{+} ;\left[\mathrm{M}^{+}\right]} \\
277.2(45)\left[\left(\mathrm{C}_{6} \mathrm{H}_{3} \mathrm{O}\right)_{2} \mathrm{PS}_{2}\right]^{-} ; \\
{\left[\mathrm{M}^{+}\right] 201.2(56)\left[m-\mathrm{CH}_{3} \mathrm{C}_{6} \mathrm{H}_{3} \mathrm{OPS}_{2}\right]^{-} ;} \\
{\left[\mathrm{M}^{+}\right]^{\dagger} 141.5(65), 143.5(34), 145.5(19)\left[p-\mathrm{Cl}-m-\mathrm{CH}_{3} \mathrm{C}_{6} \mathrm{H}_{3} \mathrm{O}\right]^{-} ;} \\
{\left[\mathrm{M}^{+}\right] 106.1(91)\left[m-\mathrm{CH}_{3} \mathrm{C}_{6} \mathrm{H}_{3} \mathrm{O}\right]^{-} ;}\end{array}$ \\
\hline 17. & 1198.2 & $\begin{array}{l}{\left[\mathrm{M}^{+}\right] 1198.2(6)\left[\left\{\left(o-\mathrm{CH}_{3} \mathrm{C}_{6} \mathrm{H}_{4} \mathrm{O}\right)_{2} \mathrm{PS}_{2}\right\}_{2} \mathrm{Mn} \cdot 2 \mathrm{P}\left(\mathrm{C}_{6} \mathrm{H}_{5}\right)_{3}\right]^{+} ;} \\
{\left[\mathrm{M}^{+}\right] 364.3(10)\left[\left\{\left(o-\mathrm{CH}_{3} \mathrm{C}_{6} \mathrm{H}_{4} \mathrm{O}\right)_{2} \mathrm{PS}_{2}\right\} \mathrm{Mn}\right]^{+} ;} \\
{\left[\mathrm{M}^{+}\right] 202.2(18)\left[o-\mathrm{CH}_{3} \mathrm{C}_{6} \mathrm{H}_{4} \mathrm{OPS}_{2}\right]^{-} ;} \\
{\left[\mathrm{M}^{+}\right] 277.1(7)\left[\mathrm{Mn}\left(\mathrm{S}_{2} \mathrm{PO}\right)_{2}\right]^{+}} \\
{\left[\mathrm{M}^{+}\right] 107.1(20)\left[o-\mathrm{CH}_{3} \mathrm{C}_{6} \mathrm{H}_{4} \mathrm{O}\right]^{-} ;}\end{array}$ \\
\hline 19. & 1198.2 & $\begin{array}{l}{\left[\mathrm{M}^{+}\right] 1198.2(8)\left[\left\{\left(p-\mathrm{CH}_{3} \mathrm{C}_{6} \mathrm{H}_{4} \mathrm{O}\right)_{2} \mathrm{PS}_{2}\right\}_{2} \mathrm{Mn} \cdot 2 \mathrm{P}\left(\mathrm{C}_{6} \mathrm{H}_{5}\right)_{3}\right]^{+} ;} \\
{\left[\mathrm{M}^{+}\right] \text {364.3 (10) }\left[\left\{\left(p-\mathrm{CH}_{3} \mathrm{C}_{6} \mathrm{H}_{4} \mathrm{O}\right)_{2} \mathrm{PS}_{2}\right\} \mathrm{Mn}\right]^{+} ;} \\
{\left[\mathrm{M}^{+}\right] 278.7(98)\left[\left(p-\mathrm{C}_{6} \mathrm{H}_{4} \mathrm{O}\right)_{2} \mathrm{PS}_{2}\right]^{-}} \\
{\left[\mathrm{M}^{+}\right] \text {202.2(18) }\left[p-\mathrm{CH}_{3} \mathrm{C}_{6} \mathrm{H}_{4} \mathrm{OPS}_{2}\right]^{-}} \\
{\left[\mathrm{M}^{+}\right] \text {107.1 (20) }\left[p-\mathrm{CH}_{3} \mathrm{C}_{6} \mathrm{H}_{4} \mathrm{O}\right]^{-} ;}\end{array}$ \\
\hline
\end{tabular}

${ }^{\dagger}$ isotopic peaks.

residue is $14.14 \%$ of the initial weight of the sample; this corresponds to the formation of MnS contaminated with other thermolysis products (the calculated value is $10.09 \%$ ) at $788.99^{\circ} \mathrm{C}$.

The DSC curve for the complex $\left[\left\{\left(o-\mathrm{CH}_{3} \mathrm{C}_{6} \mathrm{H}_{4} \mathrm{O}\right)_{2}\right.\right.$ $\left.\mathrm{PS}_{2}\right\}_{2} \mathrm{Mn}$ ] shows an endotherm in the region of stability of
$\left[\mathrm{Mn}\left(\mathrm{S}_{2} \mathrm{PO}\right)_{2}\right]$ near $151.7^{\circ} \mathrm{C}$. Two endotherms are observed for the adduct $\left[\left\{\left(o-\mathrm{CH}_{3} \mathrm{C}_{6} \mathrm{H}_{4} \mathrm{O}\right)_{2} \mathrm{PS}_{2}\right\}_{2} \mathrm{Mn} \cdot \mathrm{N}_{2} \mathrm{C}_{12} \mathrm{H}_{8}\right]$, one sharp endotherm (extrapolated to $68.99^{\circ} \mathrm{C}$ ) corresponds to the weight loss leading to the formation of $\left[\left\{\left(o-\mathrm{CH}_{3} \mathrm{C}_{6} \mathrm{H}_{4} \mathrm{O}\right)_{2}\right.\right.$ $\left.\mathrm{PS}_{2}\right\}_{2} \mathrm{Mn}$ ], and a less intense endotherm appears in the region of formation of $\left[\mathrm{Mn}\left(\mathrm{S}_{2} \mathrm{PO}\right)_{2}\right]$. 


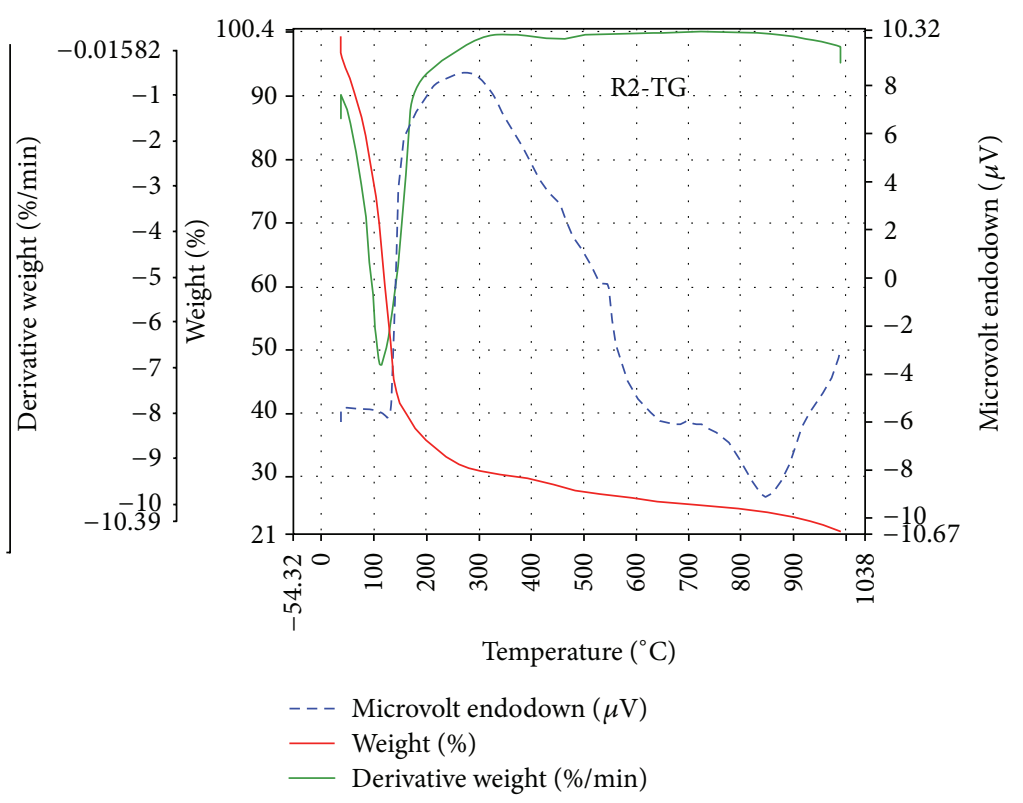

Figure 1: TGA curve of complex $\left[\left\{\left(o-\mathrm{CH}_{3} \mathrm{C}_{6} \mathrm{H}_{4} \mathrm{O}\right)_{2} \mathrm{PS}_{2}\right\}_{2} \mathrm{Mn}\right](\mathbf{1})$.



Figure 2: TGA curve of $\left[\left\{\left(o-\mathrm{CH}_{3} \mathrm{C}_{6} \mathrm{H}_{4} \mathrm{O}\right)_{2} \mathrm{PS}_{2}\right\}_{2} \mathrm{Mn} \cdot \mathrm{N}_{2} \mathrm{C}_{12} \mathrm{H}_{8}\right](5)$.

3.7. Cyclic Voltammetry. The complex $\left[\left\{\left(o-\mathrm{CH}_{3} \mathrm{C}_{6} \mathrm{H}_{4} \mathrm{O}\right)_{2}\right.\right.$ $\left.\left.\mathrm{PS}_{2}\right\}_{2} \mathrm{Mn} \cdot 2 \mathrm{P}\left(\mathrm{C}_{6} \mathrm{H}_{5}\right)_{3}\right](17)$ is electroactive with respect to the metal center. The cyclic voltammogram (Figure 3 ) of the complex in the potential range of +2.5 to $-1.5 \mathrm{~V}$ at a scan rate of $100 \mathrm{mV} / \mathrm{s}$ exhibited two redox processes; each reduction is associated with a single-electron transfer process. Two well-defined one-electron cyclic responses were observed as discussed in Table 5. The first reduction peak was observed at $E_{p c}=1.878 \mathrm{~V}$ with the cathodic peak current, $i_{c}=5.56 \times$ $10^{-5} \mathrm{~A}$, and a corresponding oxidation peak at $E_{p a}=-0.465 \mathrm{~V}$ with the anodic peak current, $i_{c}=-2.27 \times 10^{-5} \mathrm{~A}$. The second redox process was related with the reduction peak at $E_{p c}=$ $-1.127 \mathrm{~V}$ with the cathodic peak current, $i_{c}=-3.19 \times 10^{-5} \mathrm{~A}$, with a corresponding oxidation peak at $E_{p a}=0.733 \mathrm{~V}$ with the anodic peak current, $i_{c}=-1.2 \times 10^{-5} \mathrm{~A}$.

\subsection{Antimicrobial Screening}

3.8.1. Antibacterial. The bacterial species under investigation were the strains of three human pathogenic gram negative bacteria: Escherichia coli, Klebsiella pneumonia, and 
TABLE 4: Magnetic moment and electronic spectral data for the $\mathrm{Mn}$ (II) ditolyldithiophosphates.

\begin{tabular}{|c|c|c|c|}
\hline S. no. & $\mu_{\mathrm{eff}}$ & $\lambda_{\max }(\mathrm{nm})$ & Assignments \\
\hline \multirow{3}{*}{1.} & \multirow{3}{*}{-} & 347 & ${ }^{6} \mathrm{~A}_{\mathrm{lg}} \rightarrow{ }^{4} \mathrm{E}_{\mathrm{g}}\left({ }^{4} \mathrm{D}\right)$ \\
\hline & & 431 & ${ }^{6} \mathrm{~A}_{1 \mathrm{~g}} \rightarrow{ }^{4} \mathrm{E}_{\mathrm{g}}\left({ }^{4} \mathrm{G}\right)$ \\
\hline & & 510 & ${ }^{6} \mathrm{~A}_{\mathrm{lg}} \rightarrow{ }^{4} \mathrm{~T}_{\mathrm{lg}}\left({ }^{4} \mathrm{G}\right)$ \\
\hline \multirow{3}{*}{2.} & \multirow{3}{*}{-} & 339 & ${ }^{6} \mathrm{~A}_{\mathrm{lg}} \rightarrow{ }^{4} \mathrm{E}_{\mathrm{g}}\left({ }^{4} \mathrm{D}\right)$ \\
\hline & & 435 & ${ }^{6} \mathrm{~A}_{\mathrm{lg}} \rightarrow{ }^{4} \mathrm{E}_{\mathrm{g}}\left({ }^{4} \mathrm{G}\right)$ \\
\hline & & 512 & ${ }^{6} \mathrm{~A}_{1 \mathrm{~g}} \rightarrow{ }^{4} \mathrm{~T}_{\mathrm{lg}}\left({ }^{4} \mathrm{G}\right)$ \\
\hline \multirow{3}{*}{3.} & \multirow{3}{*}{-} & 344 & ${ }^{6} \mathrm{~A}_{\mathrm{lg}} \rightarrow{ }^{4} \mathrm{E}_{\mathrm{g}}\left({ }^{4} \mathrm{D}\right)$ \\
\hline & & 433 & ${ }^{6} \mathrm{~A}_{\mathrm{lg}} \rightarrow{ }^{4} \mathrm{E}_{\mathrm{g}}\left({ }^{4} \mathrm{G}\right)$ \\
\hline & & 517 & ${ }^{6} \mathrm{~A}_{1 \mathrm{~g}} \rightarrow{ }^{4} \mathrm{~T}_{1 \mathrm{~g}}\left({ }^{4} \mathrm{G}\right)$ \\
\hline \multirow{3}{*}{4.} & \multirow{3}{*}{5.90} & 341 & ${ }^{6} \mathrm{~A}_{\mathrm{lg}} \rightarrow{ }^{4} \mathrm{E}_{\mathrm{g}}\left({ }^{4} \mathrm{D}\right)$ \\
\hline & & 432 & ${ }^{6} \mathrm{~A}_{\mathrm{lg}} \rightarrow{ }^{4} \mathrm{E}_{\mathrm{g}}\left({ }^{4} \mathrm{G}\right)$ \\
\hline & & 514 & ${ }^{6} \mathrm{~A}_{1 \mathrm{~g}} \rightarrow{ }^{4} \mathrm{~T}_{1 \mathrm{lg}}\left({ }^{4} \mathrm{G}\right)$ \\
\hline \multirow{4}{*}{5.} & \multirow{4}{*}{-} & 370 & ${ }^{6} \mathrm{~A}_{\mathrm{lg}} \rightarrow{ }^{4} \mathrm{E}_{\mathrm{g}}\left({ }^{4} \mathrm{D}\right)$ \\
\hline & & 449 & ${ }^{6} \mathrm{~A}_{\mathrm{lg}} \rightarrow{ }^{4} \mathrm{E}_{\mathrm{g}}\left({ }^{4} \mathrm{G}\right)$ \\
\hline & & 536 & ${ }^{6} \mathrm{~A}_{\mathrm{lg}} \rightarrow{ }^{4} \mathrm{~T}_{\mathrm{lg}}\left({ }^{4} \mathrm{G}\right)$ \\
\hline & & 269,286 & Charge transfer \\
\hline \multirow{4}{*}{6.} & \multirow{4}{*}{5.60} & 365 & ${ }^{6} \mathrm{~A}_{1 \mathrm{~g}} \rightarrow{ }^{4} \mathrm{E}_{\mathrm{g}}\left({ }^{4} \mathrm{D}\right)$ \\
\hline & & 452 & ${ }^{6} \mathrm{~A}_{\mathrm{lg}} \rightarrow{ }^{4} \mathrm{E}_{\mathrm{g}}\left({ }^{4} \mathrm{G}\right)$ \\
\hline & & 542 & ${ }^{6} \mathrm{~A}_{\mathrm{lg}} \rightarrow{ }^{4} \mathrm{~T}_{\mathrm{lg}}\left({ }^{4} \mathrm{G}\right)$ \\
\hline & & 271,285 & Charge transfer \\
\hline \multirow{4}{*}{7.} & \multirow{4}{*}{-} & 373 & ${ }^{6} \mathrm{~A}_{\mathrm{lg}} \rightarrow{ }^{4} \mathrm{E}_{\mathrm{g}}\left({ }^{4} \mathrm{D}\right)$ \\
\hline & & 456 & ${ }^{6} \mathrm{~A}_{\mathrm{lg}} \rightarrow{ }^{4} \mathrm{E}_{\mathrm{g}}\left({ }^{4} \mathrm{G}\right)$ \\
\hline & & 538 & ${ }^{6} \mathrm{~A}_{\mathrm{lg}} \rightarrow{ }^{4} \mathrm{~T}_{\mathrm{lg}}\left({ }^{4} \mathrm{G}\right)$ \\
\hline & & 264,286 & Charge transfer \\
\hline \multirow{4}{*}{8.} & \multirow{4}{*}{-} & 364 & ${ }^{6} \mathrm{~A}_{1 \mathrm{~g}} \rightarrow{ }^{4} \mathrm{E}_{\mathrm{g}}\left({ }^{4} \mathrm{D}\right)$ \\
\hline & & 465 & ${ }^{6} \mathrm{~A}_{\mathrm{lg}} \rightarrow{ }^{4} \mathrm{E}_{\mathrm{g}}\left({ }^{4} \mathrm{G}\right)$ \\
\hline & & 532 & ${ }^{6} \mathrm{~A}_{\mathrm{lg}} \rightarrow{ }^{4} \mathrm{~T}_{\mathrm{lg}}\left({ }^{4} \mathrm{G}\right)$ \\
\hline & & 264,284 & Charge transfer \\
\hline \multirow{4}{*}{9.} & \multirow{4}{*}{5.68} & 363 & ${ }^{6} \mathrm{~A}_{\mathrm{lg}} \rightarrow{ }^{4} \mathrm{E}_{\mathrm{g}}\left({ }^{4} \mathrm{D}\right)$ \\
\hline & & 450 & ${ }^{6} \mathrm{~A}_{\mathrm{lg}} \rightarrow{ }^{4} \mathrm{E}_{\mathrm{g}}\left({ }^{4} \mathrm{G}\right)$ \\
\hline & & 540 & ${ }^{6} \mathrm{~A}_{\mathrm{lg}} \rightarrow{ }^{4} \mathrm{~T}_{1 \mathrm{~g}}\left({ }^{4} \mathrm{G}\right)$ \\
\hline & & 271,283 & Charge transfer \\
\hline \multirow{4}{*}{10.} & \multirow{4}{*}{ - } & 361 & ${ }^{6} \mathrm{~A}_{\mathrm{lg}} \rightarrow{ }^{4} \mathrm{E}_{\mathrm{g}}\left({ }^{4} \mathrm{D}\right)$ \\
\hline & & 446 & ${ }^{6} \mathrm{~A}_{\mathrm{lg}} \rightarrow{ }^{4} \mathrm{E}_{\mathrm{g}}\left({ }^{4} \mathrm{G}\right)$ \\
\hline & & 536 & ${ }^{6} \mathrm{~A}_{\mathrm{lg}} \rightarrow{ }^{4} \mathrm{~T}_{\mathrm{lg}}\left({ }^{4} \mathrm{G}\right)$ \\
\hline & & 266,285 & Charge transfer \\
\hline \multirow{4}{*}{11.} & & 359 & ${ }^{6} \mathrm{~A}_{\mathrm{lg}} \rightarrow{ }^{4} \mathrm{E}_{\mathrm{g}}\left({ }^{4} \mathrm{D}\right)$ \\
\hline & - & 445 & ${ }^{6} \mathrm{~A}_{\mathrm{lg}} \rightarrow{ }^{4} \mathrm{E}_{\mathrm{g}}\left({ }^{4} \mathrm{G}\right)$ \\
\hline & & 533 & ${ }^{6} \mathrm{~A}_{\mathrm{lg}} \rightarrow{ }^{4} \mathrm{~T}_{\mathrm{lg}}\left({ }^{4} \mathrm{G}\right)$ \\
\hline & & 270,282 & Charge transfer \\
\hline & & 370 & ${ }^{6} \mathrm{~A}_{\mathrm{lg}} \rightarrow{ }^{4} \mathrm{E}_{\mathrm{g}}\left({ }^{4} \mathrm{D}\right)$ \\
\hline 12 & - & 453 & ${ }^{6} \mathrm{~A}_{\mathrm{lg}} \rightarrow{ }^{4} \mathrm{E}_{\mathrm{g}}\left({ }^{4} \mathrm{G}\right)$ \\
\hline & & 539 & ${ }^{6} \mathrm{~A}_{\mathrm{lg}} \rightarrow{ }^{4} \mathrm{~T}_{\mathrm{lg}}\left({ }^{4} \mathrm{G}\right)$ \\
\hline & & 269,280 & Charge transfer \\
\hline & & 396 & ${ }^{6} \mathrm{~A}_{\mathrm{lg}} \rightarrow{ }^{4} \mathrm{E}_{\mathrm{g}}\left({ }^{4} \mathrm{D}\right)$ \\
\hline 13 & - & 479 & ${ }^{6} \mathrm{~A}_{\mathrm{lg}} \rightarrow{ }^{4} \mathrm{E}_{\mathrm{g}}\left({ }^{4} \mathrm{G}\right)$ \\
\hline & & 542 & ${ }^{6} \mathrm{~A}_{\mathrm{lg}} \rightarrow{ }^{4} \mathrm{~T}_{\mathrm{lg}}\left({ }^{4} \mathrm{G}\right)$ \\
\hline & & 273,294 & Charge transfer \\
\hline & & 390 & ${ }^{6} \mathrm{~A}_{\mathrm{lg}} \rightarrow{ }^{4} \mathrm{E}_{\mathrm{g}}\left({ }^{4} \mathrm{D}\right)$ \\
\hline 14. & - & 472 & ${ }^{6} \mathrm{~A}_{\mathrm{lg}} \rightarrow{ }^{4} \mathrm{E}_{\mathrm{g}}\left({ }^{4} \mathrm{G}\right)$ \\
\hline & & 573 & ${ }^{6} \mathrm{~A}_{\mathrm{lg}} \rightarrow{ }^{4} \mathrm{~T}_{\mathrm{lg}}\left({ }^{4} \mathrm{G}\right)$ \\
\hline & & 270,296 & Charge transfer \\
\hline
\end{tabular}

TABLE 4: Continued.

\begin{tabular}{|c|c|c|c|}
\hline S. no. & $\mu_{\mathrm{eff}}$ & $\lambda_{\max }(\mathrm{nm})$ & Assignments \\
\hline \multirow{4}{*}{15.} & \multirow{4}{*}{-} & 393 & ${ }^{6} \mathrm{~A}_{1 \mathrm{~g}} \rightarrow{ }^{4} \mathrm{E}_{\mathrm{g}}\left({ }^{4} \mathrm{D}\right)$ \\
\hline & & 478 & ${ }^{6} \mathrm{~A}_{\mathrm{lg}} \rightarrow{ }^{4} \mathrm{E}_{\mathrm{g}}\left({ }^{4} \mathrm{G}\right)$ \\
\hline & & 549 & ${ }^{6} \mathrm{~A}_{\mathrm{lg}} \rightarrow{ }^{4} \mathrm{~T}_{\mathrm{lg}}\left({ }^{4} \mathrm{G}\right)$ \\
\hline & & 273,294 & Charge transfer \\
\hline \multirow{4}{*}{16.} & \multirow{4}{*}{5.65} & 390 & ${ }^{6} \mathrm{~A}_{\mathrm{lg}} \rightarrow{ }^{4} \mathrm{E}_{\mathrm{g}}\left({ }^{4} \mathrm{D}\right)$ \\
\hline & & 470 & ${ }^{6} \mathrm{~A}_{1 \mathrm{~g}} \rightarrow{ }^{4} \mathrm{E}_{\mathrm{g}}\left({ }^{4} \mathrm{G}\right)$ \\
\hline & & 565 & ${ }^{6} \mathrm{~A}_{\mathrm{lg}} \rightarrow{ }^{4} \mathrm{~T}_{\mathrm{lg}}{ }^{8}\left({ }^{4} \mathrm{G}\right)$ \\
\hline & & 277,295 & Charge transfer \\
\hline \multirow{4}{*}{17.} & \multirow{4}{*}{-} & 352 & ${ }^{6} \mathrm{~A}_{\mathrm{lg}} \rightarrow{ }^{4} \mathrm{E}_{\mathrm{g}}\left({ }^{4} \mathrm{D}\right)$ \\
\hline & & 435 & ${ }^{6} \mathrm{~A}_{\mathrm{lg}} \rightarrow{ }^{4} \mathrm{E}_{\mathrm{g}}\left({ }^{4} \mathrm{G}\right)$ \\
\hline & & 524 & ${ }^{6} \mathrm{~A}_{\mathrm{lg}} \rightarrow{ }^{4} \mathrm{~T}_{\mathrm{lg}}\left({ }^{4} \mathrm{G}\right)$ \\
\hline & & 253,276 & Charge transfer \\
\hline \multirow{4}{*}{18.} & \multirow{4}{*}{-} & 356 & ${ }^{6} \mathrm{~A}_{\mathrm{lg}} \rightarrow{ }^{4} \mathrm{E}_{\mathrm{g}}\left({ }^{4} \mathrm{D}\right)$ \\
\hline & & 447 & ${ }^{6} \mathrm{~A}_{\mathrm{lg}} \rightarrow{ }^{4} \mathrm{E}_{\mathrm{g}}\left({ }^{4} \mathrm{G}\right)$ \\
\hline & & 521 & ${ }^{6} \mathrm{~A}_{\mathrm{lg}} \rightarrow{ }^{4} \mathrm{~T}_{\mathrm{lg}}\left({ }^{4} \mathrm{G}\right)$ \\
\hline & & 247,274 & Charge transfer \\
\hline \multirow{4}{*}{19.} & \multirow{4}{*}{5.76} & 353 & ${ }^{6} \mathrm{~A}_{\mathrm{lg}} \rightarrow{ }^{4} \mathrm{E}_{\mathrm{g}}\left({ }^{4} \mathrm{D}\right)$ \\
\hline & & 432 & ${ }^{6} \mathrm{~A}_{\mathrm{lg}} \rightarrow{ }^{4} \mathrm{E}_{\mathrm{g}}\left({ }^{4} \mathrm{G}\right)$ \\
\hline & & 525 & ${ }^{6} \mathrm{~A}_{\mathrm{lg}} \rightarrow{ }^{4} \mathrm{~T}_{\mathrm{lg}}\left({ }^{4} \mathrm{G}\right)$ \\
\hline & & 251,273 & Charge transfer \\
\hline \multirow{4}{*}{20.} & \multirow{4}{*}{-} & 356 & ${ }^{6} \mathrm{~A}_{\mathrm{lg}} \rightarrow{ }^{4} \mathrm{E}_{\mathrm{g}}\left({ }^{4} \mathrm{D}\right)$ \\
\hline & & 442 & ${ }^{6} \mathrm{~A}_{\mathrm{lg}} \rightarrow{ }^{4} \mathrm{E}_{\mathrm{g}}\left({ }^{4} \mathrm{G}\right)$ \\
\hline & & 528 & ${ }^{6} \mathrm{~A}_{\mathrm{lg}} \rightarrow{ }^{4} \mathrm{~T}_{\mathrm{lg}}\left({ }^{4} \mathrm{G}\right)$ \\
\hline & & 249,275 & Charge transfer \\
\hline
\end{tabular}



Figure 3: Cyclic voltammetric curve of complex $\left[\left\{\left(o-\mathrm{CH}_{3} \mathrm{C}_{6} \mathrm{H}_{4} \mathrm{O}\right)_{2}\right.\right.$ $\left.\left.\mathrm{PS}_{2}\right\}_{2} \mathrm{Mn} \cdot 2 \mathrm{P}\left(\mathrm{C}_{6} \mathrm{H}_{5}\right)_{3}\right](17)$.

Pseudomonas aeruginosa. The free ligands, $\mathrm{MnCl}_{2} \cdot 4 \mathrm{H}_{2} \mathrm{O}$, and a few complexes were screened for their in vitro antibacterial study by well diffusion method [35]. The results achieved by these studies have been enlisted in Table 6. The antibacterial data reveals that $\mathrm{MnCl}_{2} \cdot 4 \mathrm{H}_{2} \mathrm{O}$ in solution shows prominent inhibition capacities while the free ligands did not possess antibacterial properties against the bacterial species under study. The results also confirmed 
TABLE 5: Cyclic voltammetric analysis data of complex $\left[\left\{\left(o-\mathrm{CH}_{3} \mathrm{C}_{6} \mathrm{H}_{4} \mathrm{O}\right)_{2} \mathrm{PS}_{2}\right\}_{2} \mathrm{Mn} \cdot 2 \mathrm{P}\left(\mathrm{C}_{6} \mathrm{H}_{5}\right)_{3}\right](\mathbf{1 7})$.

\begin{tabular}{lccccc}
\hline Index & Peak position & Peak height & Base start & Base end & 2.2739 \\
1 & 1.8784 & $5.56 \times 10^{-5}$ & 1.3754 & 0.29762 \\
2 & 0.73334 & $-1.22 \times 10^{-5}$ & 0.64056 & 0.91644 & -0.07277 \\
3 & -1.127 & $3.19 \times 10^{-5}$ & -1.4835 & -0.46295 & 0.25486 \\
4 & -0.46539 & $-2.27 \times 10^{-5}$ & -0.7193 & -0.16754 & -0.17766 \\
\hline
\end{tabular}

TABle 6: Antibacterial activities of the Mn(II) ditolyldithiophosphates (zone of inhibition, in mm).

\begin{tabular}{|c|c|c|c|c|}
\hline \multirow{2}{*}{ Compound } & \multirow{2}{*}{ Concentration (ppm) } & \multicolumn{3}{|c|}{ Bacterial species } \\
\hline & & Escherichia coli & Klebsiella pneumonia & Pseudomonas aeruginosa \\
\hline \multirow{4}{*}{$\begin{array}{l}\text { Ciprofloxacin } \\
\text { (standard drug) }\end{array}$} & 50 & 1.4 & 2.5 & 2.6 \\
\hline & 100 & 1.8 & 2.7 & 2.9 \\
\hline & 150 & 1.9 & 2.8 & 3.0 \\
\hline & 200 & 2.1 & 2.9 & 3.5 \\
\hline \multirow{4}{*}{$\begin{array}{l}\mathrm{MnCl}_{2} \cdot 4 \mathrm{H}_{2} \mathrm{O} \\
\text { (metal salt) }\end{array}$} & 50 & 2.4 & 2.6 & 2.9 \\
\hline & 100 & 2.6 & 2.8 & 3.0 \\
\hline & 150 & 2.9 & 3.0 & 3.4 \\
\hline & 200 & 3.0 & 3.1 & 3.6 \\
\hline \multirow{4}{*}{$\begin{array}{l}\text { Free ligand } \\
\left(o-\mathrm{CH}_{3} \mathrm{C}_{6} \mathrm{H}_{4} \mathrm{O}\right)_{2} \mathrm{PS}_{2} \mathrm{Na}\end{array}$} & 50 & 0.0 & 0.0 & 0.0 \\
\hline & 100 & 0.0 & 0.0 & 0.0 \\
\hline & 150 & 0.0 & 0.0 & 0.0 \\
\hline & 200 & 0.0 & 0.0 & 0.0 \\
\hline \multirow{4}{*}{ (1) } & 50 & 1.7 & 1.7 & 1.8 \\
\hline & 100 & 1.9 & 1.9 & 2.1 \\
\hline & 150 & 2.1 & 2.1 & 2.6 \\
\hline & 200 & 2.3 & 2.5 & 3.2 \\
\hline \multirow{4}{*}{ (5) } & 50 & 1.6 & 2.1 & 2.5 \\
\hline & 100 & 1.9 & 2.3 & 2.6 \\
\hline & 150 & 2.3 & 2.5 & 2.8 \\
\hline & 200 & 2.5 & 2.8 & 3.0 \\
\hline
\end{tabular}

that the antimicrobial activity of the metal chelates shows more inhibitory effects than the parent ligand. Furthermore, the $\left[\left\{\left(o-\mathrm{CH}_{3} \mathrm{C}_{6} \mathrm{H}_{4} \mathrm{O}\right)_{2} \mathrm{PS}_{2}\right\}_{2} \mathrm{Mn} \cdot \mathrm{N}_{2} \mathrm{C}_{12} \mathrm{H}_{8}\right]$ (5) exhibited enhanced activity than the $\left[\left\{\left(o-\mathrm{CH}_{3} \mathrm{C}_{6} \mathrm{H}_{4} \mathrm{O}\right)_{2} \mathrm{PS}_{2}\right\}_{2} \mathrm{Mn}\right]$ (1). On chelation, the polarity of the metal ion will reduce to a greater extent due to the overlap of the ligand orbital and partial sharing of the positive charge of the metal ion with donor groups [36]. Further, it increases the delocalization of $\pi$-electrons around the whole chelate ring and enhances the penetration of the complexes into lipid membranes and blocking of the metal binding sites in the enzymes of microorganisms. These complexes also disturb the respiration process of the cell and thus block the synthesis of proteins, which restricts further growth of the organisms. It has also been observed that concentration plays a vital role in increasing the degree of inhibition. The inhibition is directly proportional to the concentration. The bacterial growth inhibitory capacity of ligand and its complexes with manganese(II) have also been illustrated in Figures 4(a)-4(d).

3.8.2. Antifungal. The antifungal activity of ligands and a few representative metal complexes were evaluated by the poisoned food technique [35] against plant pathogenic strain, S. rolfsii. The antifungal screening data are given in Table 7 , which shows that the colony diameter of the fungus decreases as the concentration of the complex increases; that is, 




(a)



(c)

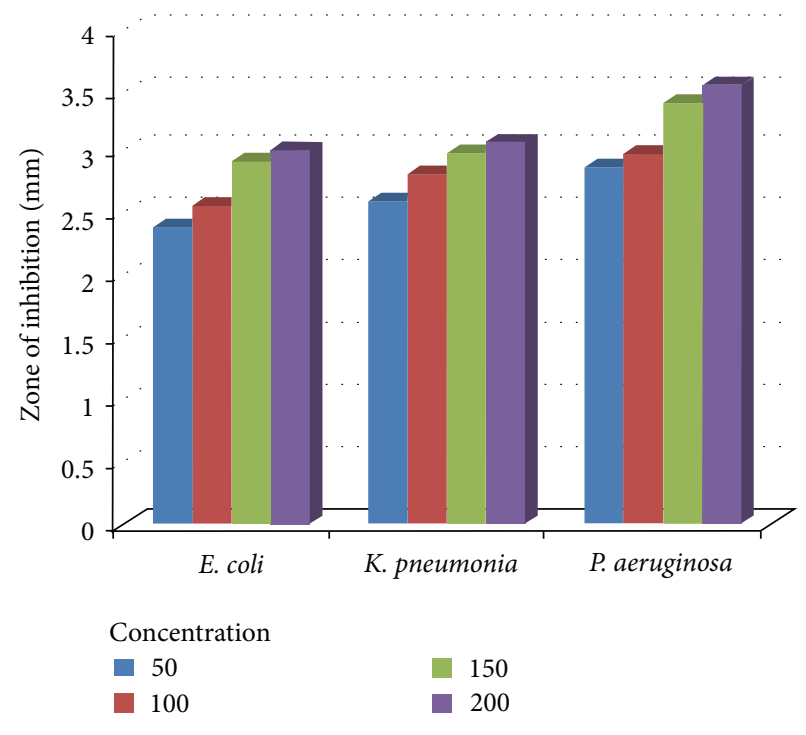

(b)



(d)

Figure 4: Comparative results of antibacterial screening data for: (a) Ciprofloxacin (drug), (b) $\mathrm{MnCl}_{2} \cdot 4 \mathrm{H}_{2} \mathrm{O},(\mathrm{c})\left[\left\{\left(o-\mathrm{CH}_{3} \mathrm{C}_{6} \mathrm{H}_{4} \mathrm{O}\right)_{2} \mathrm{PS}_{2}\right\}_{2} \mathrm{Mn}\right]$ (1), and (d) $\left[\left\{\left(o-\mathrm{CH}_{3} \mathrm{C}_{6} \mathrm{H}_{4} \mathrm{O}\right)_{2} \mathrm{PS}_{2}\right\}_{2} \mathrm{Mn} \cdot \mathrm{N}_{2} \mathrm{C}_{12} \mathrm{H}_{8}\right](5)$.

all the complexes inhibited the growth of fungus significantly. This shows a linear relationship between concentration and percent inhibition. The increase in antimicrobial activity is due to faster diffusion of metal complexes as a whole through the cell membrane or due to combined activity effect of the metal and the ligand. It is evident from the antifungal screening data that adducts of nitrogen and phosphorus donor ligands $(\mathbf{8}, \mathbf{9}, \mathbf{1 5}$, and $\mathbf{1 8})$ are more potent than the parent complex 1. The chelation theory accounts for the increased activity of the metal complexes [36]. The results of fungi-toxicity analysis have been illustrated in Figure 5. Both antibacterial and antifungal activities were tested in the Bioassay lab, Department of Chemistry, University of Jammu, Jammu.
3.9. Structural Features. The outcome of the above results confirms the formation of the manganese(II) ditolyldithiophosphate complexes as indicated from elemental analyses, magnetic susceptibility, molar conductance, thermogravimetric, cyclic voltammetry, and spectral analyses including ESI mass spectrometry, IR, and UV-visible. The shiftings of $\nu \mathrm{P}=\mathrm{S}$ and $\nu \mathrm{P}-\mathrm{S}$ bands $\left(10-30 \mathrm{~cm}^{-1}\right)$ in comparison to the parent dithiophosphate ligands are quite diagnostic to propose bidentate mode of bonding of dithio moiety with manganese. Further, these bands have smaller gap between each other compared to the parent dithio ligand, which is also supporting the bidentate mode of attachment. The mass spectra support the respective molecular masses and fragmentation pattern as well as monomeric nature of these 


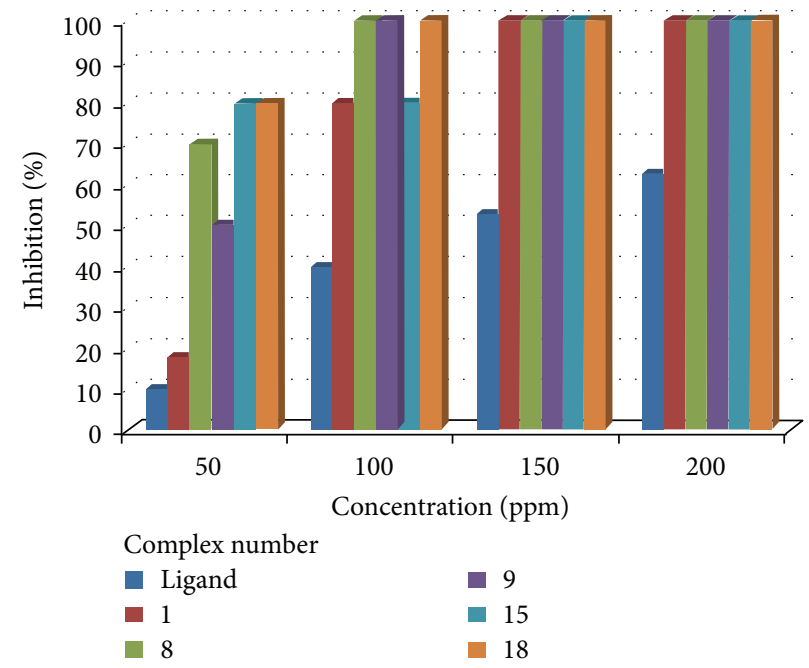

FIGURE 5: Comparative results of antifungal screening data.

TABLE 7: In vitro evaluation of $\mathrm{Mn}(\mathrm{II})$ ditolyldithiophosphates against Sclerotium rolfsii.

\begin{tabular}{|c|c|c|c|}
\hline S. no. & $\begin{array}{l}\text { Con- } \\
\text { centration } \\
(\mathrm{ppm})\end{array}$ & $\begin{array}{c}\text { Colony } \\
\text { diameter } \\
(T) \\
\text { (in } \mathrm{mm}) \\
\end{array}$ & $\begin{array}{c}\% \text { inhibition } \\
I= \\
{[(C-T) / C] \times 100}\end{array}$ \\
\hline \multirow{4}{*}{$\begin{array}{l}\text { Free ligand } \\
\left(o-\mathrm{CH}_{3} \mathrm{C}_{6} \mathrm{H}_{4} \mathrm{O}\right)_{2} \mathrm{PS}_{2} \mathrm{Na}\end{array}$} & 50 & 36 & 10 \\
\hline & 100 & 24 & 40 \\
\hline & 150 & 19 & 52.5 \\
\hline & 200 & 15 & 62.5 \\
\hline \multirow{4}{*}{1} & 50 & 41 & 18 \\
\hline & 100 & 10 & 80 \\
\hline & 150 & 0 & 100 \\
\hline & 200 & 0 & 100 \\
\hline \multirow{4}{*}{8} & 50 & 15 & 70 \\
\hline & 100 & 0 & 100 \\
\hline & 150 & 0 & 100 \\
\hline & 200 & 0 & 100 \\
\hline \multirow{4}{*}{9} & 50 & 25 & 50 \\
\hline & 100 & 0 & 100 \\
\hline & 150 & 0 & 100 \\
\hline & 200 & 0 & 100 \\
\hline \multirow{4}{*}{15} & 50 & 10 & 80 \\
\hline & 100 & 10 & 80 \\
\hline & 150 & 0 & 100 \\
\hline & 200 & 0 & 100 \\
\hline \multirow{4}{*}{18} & 50 & 10 & 80 \\
\hline & 100 & 0 & 100 \\
\hline & 150 & 0 & 100 \\
\hline & 200 & 0 & 100 \\
\hline
\end{tabular}

Mean colony diameter of control $(\mathrm{C})=50 \mathrm{~mm}$.

complexes. The UV-visible and magnetic susceptibility analysis confirmed the high spin nature of manganese atom in these complexes.<smiles>[X]c1ccc(OP23=[SH][Y12](S2)[SH]=P(Oc2ccc(C)cc2)(Oc2ccc(C)cc2)S3)cc1C</smiles>

Figure 6: Proposed square planar structure of bis- $O, O^{\prime}-(o-, m-, p-$ and $p$-Cl- $m$ - ditolyl)dithiophosphates of manganese(II) (1-4); X = $\mathrm{H}, \mathrm{CH}_{3}$, or $\mathrm{Cl}$.



$*=2,2^{\prime}$-bipyridyl<smiles>c1ccc(-c2ccccn2)nc1</smiles>

or 1,10-phenanthroline

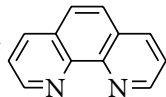

FIgURE 7: Proposed octahedral structure of manganese(II) complexes with 1,10-phenanthroline (5-8) and 2,2'-bipyridyl (9-12); X $=\mathrm{H}, \mathrm{CH}_{3}$, or $\mathrm{Cl}$.

Attempts to obtain suitable crystals for the X-ray diffraction study have so far been unsuccessful. From the above data, plausible-four and six-folded geometries may be suggested for these complexes and adducts (Figures 6, 7, and 8). 


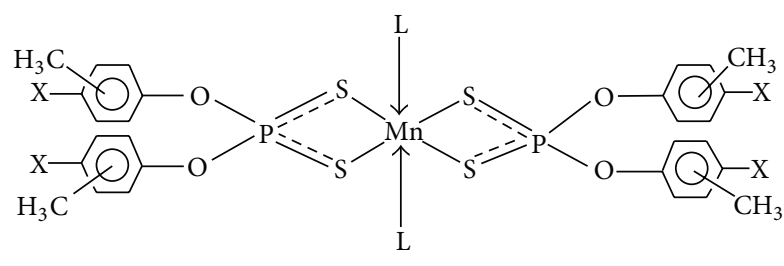

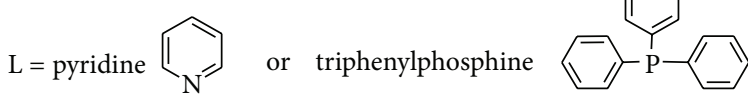

Figure 8: Proposed octahedral structure of complexes of manganese(II) with pyridine (13-16) and triphenylphosphine (17-20); $\mathrm{X}=\mathrm{H}, \mathrm{CH}_{3}$, or $\mathrm{Cl}$.

\section{Conclusion}

We have synthesized and characterized a series of twenty new $O, O^{\prime}-\left(o-, m^{-}, p-, p-C l-m\right.$-ditolyl $)$ dithiophosphate derivatives of manganese. In conjunction with the literature reports and observations based on elemental analysis, IR, mass spectral studies, and thermogravimetric analysis, bidentate chelation by the ligand to the manganese(II) ion may be postulated in these complexes. The melting points were found to be consistent with the decomposition pattern in the thermogravimetric analyses. The cyclic voltammetric analysis predicted the two electron reduction of the metal. The complexes are found to have higher biological activities as compared to the respective ligand and the parent drug.

\section{Acknowledgments}

The authours gratefully acknowledge the financial assistance from the University Grants Commission, New Delhi. they are grateful to Sophisticated Analytical Instrumentation Facility, Panjab University, Chandigarh, and Indian Institute of Integrative Medicine, Jammu, for providing spectral facilities.

\section{References}

[1] N. Greenwood and A. Earnshaw, Chemistry of the Elements, Pergamon Press, Oxford, UK, 1st edition, 1984.

[2] T. L. Stemmler, T. M. Sossong Jr., J. I. Goldstein et al., "EXAFS comparison of the dimanganese core structures of manganese catalase, arginase, and manganese-substituted ribonucleotide reductase and hemerythrin," Biochemistry, vol. 36, no. 32, pp. 9847-9858, 1997.

[3] S. Chandra and Y. Kumar, "Manganese (II) complexes of some nitrogen-oxygen and nitrogen-sulphur donor ligands," Proceedings of the Indian Academy of Sciences, vol. 92, no. 3, pp. 249-255, 1983.

[4] Y. Sugiura, H. Kawabe, H. Tanaka, S. Fujimoto, and A. Ohara, "First evidence for manganese binding to sulfur donor group in metalloprotein, Mn(III)-containing acid phosphatase," Journal of the American Chemical Society, vol. 103, no. 4, pp. 963-964, 1981.

[5] K. Greiwe, B. Krebs, and G. Henkel, "Preparation, structure, and properties of manganese toluene-3,4-dithiolate complexes in different oxidation states," Inorganic Chemistry, vol. 28, no. 19, pp. 3713-3720, 1989.

[6] P. O. Ukoha, C. U. Alioke, N. L. Obasi, and K. F. Chah, "Synthesis, spectroscopic characterization and preliminary antimicrobial studies of $\mathrm{Mn}(\mathrm{II})$ and $\mathrm{Cu}(\mathrm{II})$ complexes of two thiolates; S, $S^{\prime}$-(2,6- diaminopyridine-3,5-diyl) dibenzenecarbothioate (DBCT) and S-benzyl benzenecarbothioate (BBCT)," EJournal of Chemistry, vol. 8, no. 1, pp. 231-239, 2011.

[7] A. M. Cotero-Villegas, R.-A. Toscano, M. Muñoz-Hernández, M. López-Cardoso, P. García Y García, and R. Cea-Olivares, "Synthesis, spectroscopic characterization of $O, O^{\prime}$-alkylene dithiophosphates of tellurolane and 1-oxa-4-tellurane. Single crystal structures of $\mathrm{C}_{4} \mathrm{H}_{8} \mathrm{Te}\left[\mathrm{S}_{2} \mathrm{P}\left(\mathrm{OCH}_{2}\right)_{2} \mathrm{CMe}^{n} \mathrm{Pr}\right]_{2}$ and $\mathrm{C}_{4} \mathrm{H}_{8} \mathrm{OTe}\left[\mathrm{S}_{2} \mathrm{P}\left(\mathrm{OCH}_{2}\right)_{2} \mathrm{CEt}_{2}\right]_{2}$," Journal of Organometallic Chemistry, vol. 690, no. 12, pp. 2872-2879, 2005.

[8] N. Manwani, M. C. Gupta, R. Ratnani, J. E. Drake, M. B. Hursthouse, and M. E. Light, "Synthesis, spectroscopic characterization and structural studies of chloro dioxotriphenylphosphine oxide ( $O, O^{\prime}$-dialkyl/diphenyl(alkylene)dithiophosphate) molybdenum(VI) complexes: crystal structure of $\mathrm{MoO}_{2} \mathrm{Cl}_{2}$ $\left(\mathrm{OSMe}_{2}\right)_{2}$," Inorganica Chimica Acta, vol. 357, no. 4, pp. 939945, 2004.

[9] P. U. Jain, H. Paul, P. Munshi, M. G. Walawalkar, and G. K. Lahiri, "Osmium dithiophosphates. Synthesis, X-ray crystal structure, spectroscopic and electrochemical properties," Polyhedron, vol. 20, no. 3-4, pp. 245-252, 2001.

[10] L. Szüčová, Z. Trávníček, and J. Marek, “ $O, O$ '-dialkyldithiophosphato and $\mathrm{O}$-alkyldithiophosphato nickel(II) complexes with bidentate P-donor ligands," Polyhedron, vol. 22, no. 10, pp. 1341-1348, 2003.

[11] B. P. Singh, G. Srivastava, and R. C. Mehrotra, "Synthesis and reactions of triorganotin dialkyldithiophosphates," Journal of Organometallic Chemistry, vol. 171, no. 1, pp. 35-41, 1979.

[12] P. G. Y. García, R. Cruz-Almanza, R.-A. Toscano, and R. CeaOlivares, "Synthesis, characterization and X-ray structure of stannocanes substituted with a cyclic dithiophosphate ligand $\mathrm{X}\left(\mathrm{CH}_{2} \mathrm{CH}_{2} \mathrm{~S}\right)_{2} \mathrm{Sn}^{n} \mathrm{Bu}\left[\mathrm{S}_{2} \mathrm{P}\left(\mathrm{OCH}_{2} \mathrm{C}\left(\mathrm{Et}_{2}\right) \mathrm{CH}_{2} \mathrm{O}\right)\right],(\mathrm{X}=\mathrm{O}, \mathrm{S}): \mathrm{a}$ study about the conformational tendencies and the relationship with the anomeric effect of the stannocane rings," Journal of Organometallic Chemistry, vol. 598, no. 1, pp. 160-166, 2000.

[13] S. C. Bajia, "Synthesis and characterization of $O, O^{\prime}-(o-, m-$, $p$-Ditolyl/dibenzyl/diphenyldithiophosphate) complexes with cobalt," Synthesis and Reactivity in Inorganic, Metal-Organic and Nano-Metal Chemistry, vol. 41, no. 7, pp. 746-749, 2011.

[14] B. W. Liebich and M. Tomassini, "Bis $\left(O, O^{\prime}\right.$-diethyl dithiophosphato)diphenyltin," Acta Crystallographica B, vol. 34, pp. 944946, 1978.

[15] M.-A. Muñoz-Hernández, R. Cea-Olivares, and S. HernándezOrtega, "Synthesis and characterization of oxa and thia metallocanes substituted with phosphorodithioate ligands and crystal and molecular structure of 1,3,6-trithia-2-arsocane dimethylphosphorodithioate," Inorganica Chimica Acta, vol. 253, no. 1, pp. 31-37, 1996.

[16] V. K. Jain and B. Varghese, "Synthesis and characterization of pentamethylcyclopentadienyl-rhodium(III) dialkydithiophosphate complexes: single-crystal structure of $\left[\mathrm{Cp}^{*} \mathrm{RhCl}\right.$ $\left.\left\{\mathrm{S}_{2} \mathrm{P}(\mathrm{OEt})_{2}\right\}\right]$," Journal of Organometallic Chemistry, vol. 584, no. 1, pp. 159-163, 1999.

[17] V. K. Jain and V. S. Jakkal, "Synthesis and characterization of areneruthenium(II) dialkyldithiophosphate complexes: single crystal structure of $\left[\mathrm{Ru}\left(\mathrm{SSP}(\mathrm{OEt})_{2}\right]\left(\eta^{6}\right.\right.$-p-cymene $\left.)\left(\mathrm{PPh}_{3}\right)\right]$ 
$\left[\mathrm{BPh}_{4}\right]$," Journal of Organometallic Chemistry, vol. 515, no. 1-2, pp. 81-87, 1996.

[18] P. U. Jain, P. Munshi, M. G. Walawalkar, S. P. Rath, K. K. Rajak, and G. K. Lahiri, "Ruthenium dithiophosphates: synthesis, Xray crystal structure, spectroscopic and electrochemical properties," Polyhedron, vol. 19, no. 7, pp. 801-808, 2000.

[19] H. Kubo, "Preparation of organotin-phosphorus compounds and their biological activities," Agricultural Biology and Chemistry, vol. 29, pp. 43-55, 1965.

[20] H. So, Y. C. Lin, G. G. S. Huang, and T. S. T. Chang, "Antiwear mechanism of zinc dialkyl dithiophosphates added to a paraffinic oil in the boundary lubrication condition," Wear, vol. 166, no. 1, pp. 17-26, 1993.

[21] B. Kim, R. Mourhatch, and P. B. Aswath, "Properties of tribofilms formed with ashless dithiophosphate and zinc dialkyl dithiophosphate under extreme pressure conditions," Wear, vol. 268, no. 2-3, pp. 579-591, 2010.

[22] K. Hayashi, Y. Sasaki, S. Tagashira, and Y. Soma, "Chloroform Extraction of Thallium- $O, O^{\prime}$-Diethyldithiophosphate complexes," Analytical Sciences, vol. 2, pp. 545-548, 1986.

[23] S. Jiang, S. Dasgupta, M. Blanco et al., "Structures, vibrations, and force fields of dithiophosphate wear inhibitors from ab initio quantum chemistry," Journal of Physical Chemistry, vol. 100, no. 39, pp. 15760-15769, 1996.

[24] N. J. Mosey and T. K. Woo, "Insights into the chemical behavior of zinc dialkyldithiophosphate anti-wear additives in their isomeric and decomposed forms through molecular simulation," Tribology International, vol. 39, no. 9, pp. 979-993, 2006.

[25] N. J. Mosey and T. K. Woo, "A quantum chemical study of the unimolecular decomposition mechanisms of zinc dialkyldithiophosphate antiwear additives," Journal of Physical Chemistry A, vol. 108, no. 28, pp. 6001-6016, 2004.

[26] R. G. Cavell, E. D. Day, W. Byers, and P. M. Watkins, "Metal complexes of substituted dithiophosphinic acids. V. Complexes of manganese, iron, and cobalt," Inorganic Chemistry, vol. 11, no. 8, pp. 1759-1772, 1972.

[27] C. Denger, H. Keck, W. Kuchen, J. Mathow, and H. Wunderlich, "Synthesis, properties and structure of bis(dialkyldithiophosphinato)manganese(II) complexes," Inorganica Chimica Acta, vol. 132, no. 2, pp. 213-215, 1987.

[28] D. G. Holah and C. N. Murphy, "Reactions of Sodium N,NDiethyldithiocarbamate and Potassium Ethyl Xanthate with some 3d Transition Metal Halides in the presence of 2,2' Bipyridyl and 1,10-Phenanthroline," Canadian Journal of Chemistry, vol. 49, pp. 2726-2732, 1971.

[29] A. Kumar, K. R. Sharma, and S. K. Pandey, "Synthesis and characterization of $O, O^{\prime}-(o-, m$-, or $p$-ditolyl) dithiophosphate ligands," Phosphorus, Sulfur and Silicon and the Related Elements, vol. 182, no. 5, pp. 1023-1031, 2007.

[30] A. I. Vogel, A Textbook of Quantitative Inorganic Analysis, Longman, London, UK, 4th edition, 1978.

[31] S. Prasad, P. Jayaseelan, and R. Rajavel, "Antimicrobial and DNA cleavage studies of trinuclear $\mathrm{Cu}(\mathrm{II}), \mathrm{Ni}(\mathrm{II})$ and $\mathrm{Mn}$ (II) Schiff base complexes," International Journal of Pharmacy and Technology, vol. 2, pp. 694-707, 2010.

[32] K. Nakamoto, Infrared and Raman Spectra of Inorganic Compounds, Wiley-Interscience, New York, NY, USA, 4th edition, 1986.

[33] A. B. P. Lever, Inorganic Electronic Spectroscopy, Elsevier, Amsterdam, The Netherlands, 2nd edition, 1984.
[34] O. Siiman and H. B. Gray, "Crystal and molecular structure and $5^{\circ} \mathrm{K}$ electronic spectrum of bis(tetraphenyldithioimidodiphosphinato)manganese(II)," Inorganic Chemistry, vol. 13, no. 5, pp. 1185-1191, 1974.

[35] D. P. Singh, V. Malik, R. Kumar, and K. Kumar, “Template synthesis of macrocyclic complexes of $\mathrm{Co}(\mathrm{II}), \mathrm{Ni}(\mathrm{II}), \mathrm{Cu}(\mathrm{II})$, $\mathrm{Zn}(\mathrm{II})$ and $\mathrm{Cd}(\mathrm{II})$ : spectroscopic, antibacterial and antifungal studies," Journal of the Serbian Chemical Society, vol. 75, no. 6, pp. 763-772, 2010.

[36] B. G. Tweedy and C. Loeppky, "The use of 14C-labeled glucose, glucuronate, and acetate to study the effect of atrazine, simazine, and fluometuron on glucose catabolism in selected plant pathogenic fungi," Phytopathology, vol. 58, no. 11, pp. 15221531, 1968. 

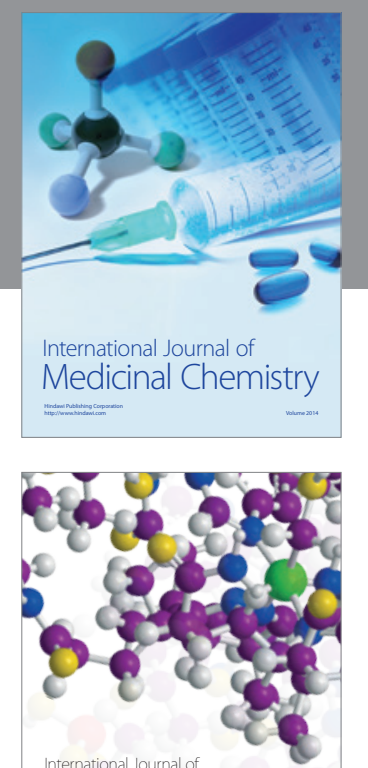

\section{Carbohydrate} Chemistry

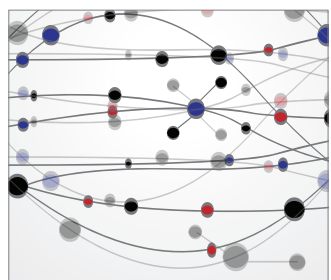

The Scientific World Journal
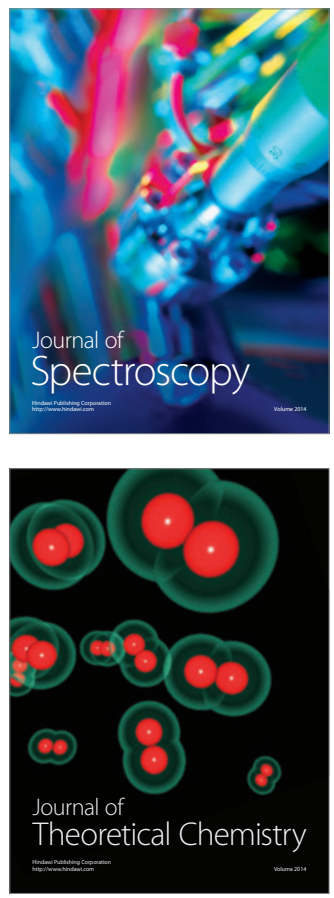
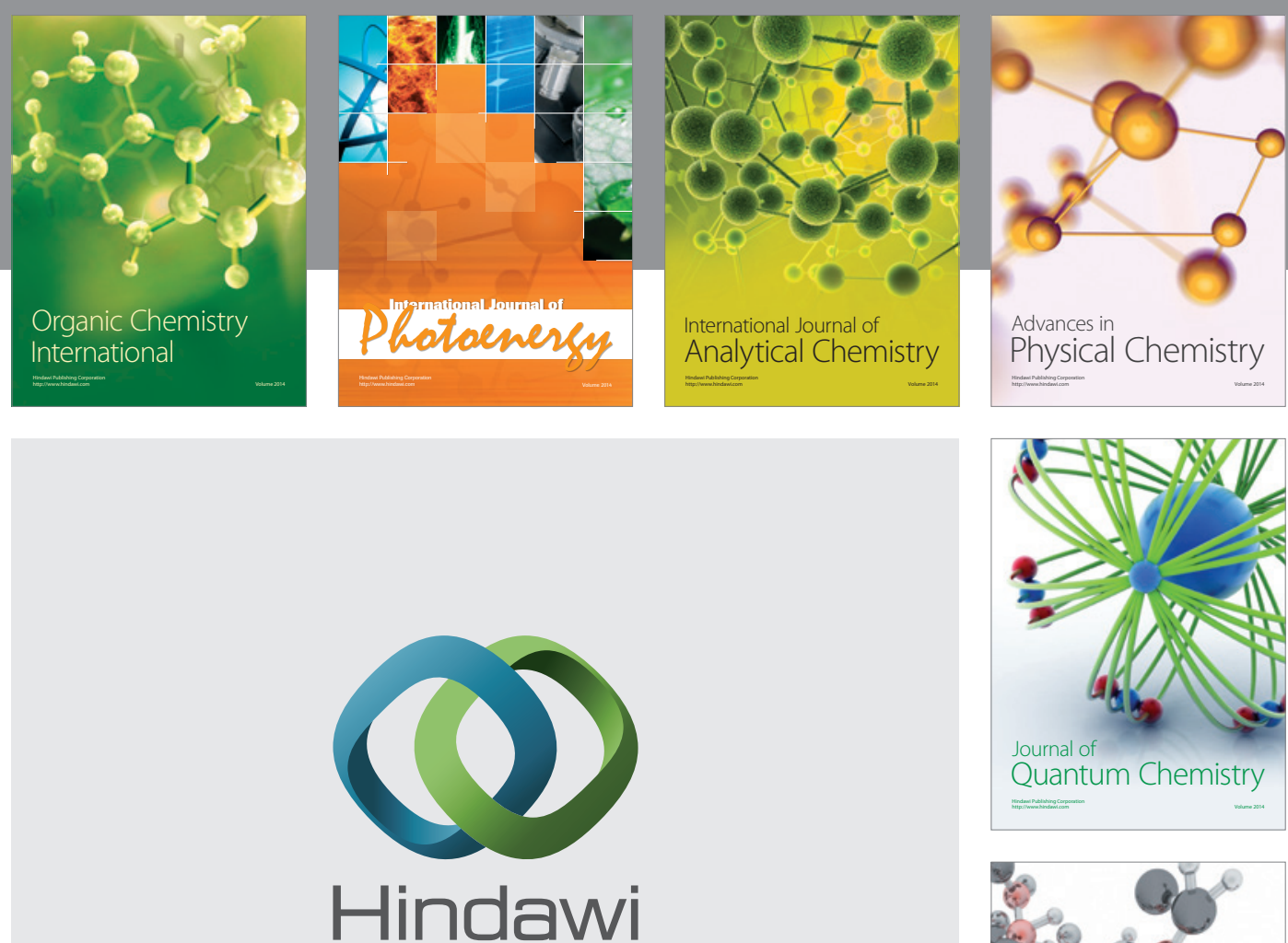

Submit your manuscripts at

http://www.hindawi.com

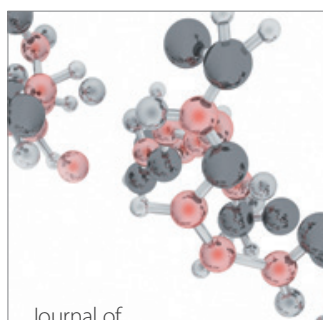

Analytical Methods

in Chemistry

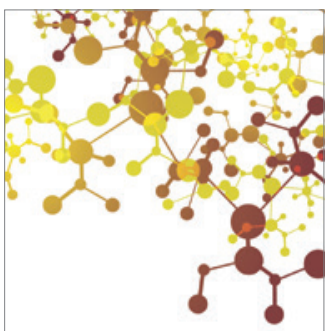

Journal of

Applied Chemistry

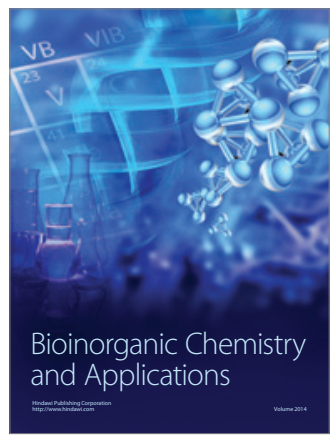

Inorganic Chemistry
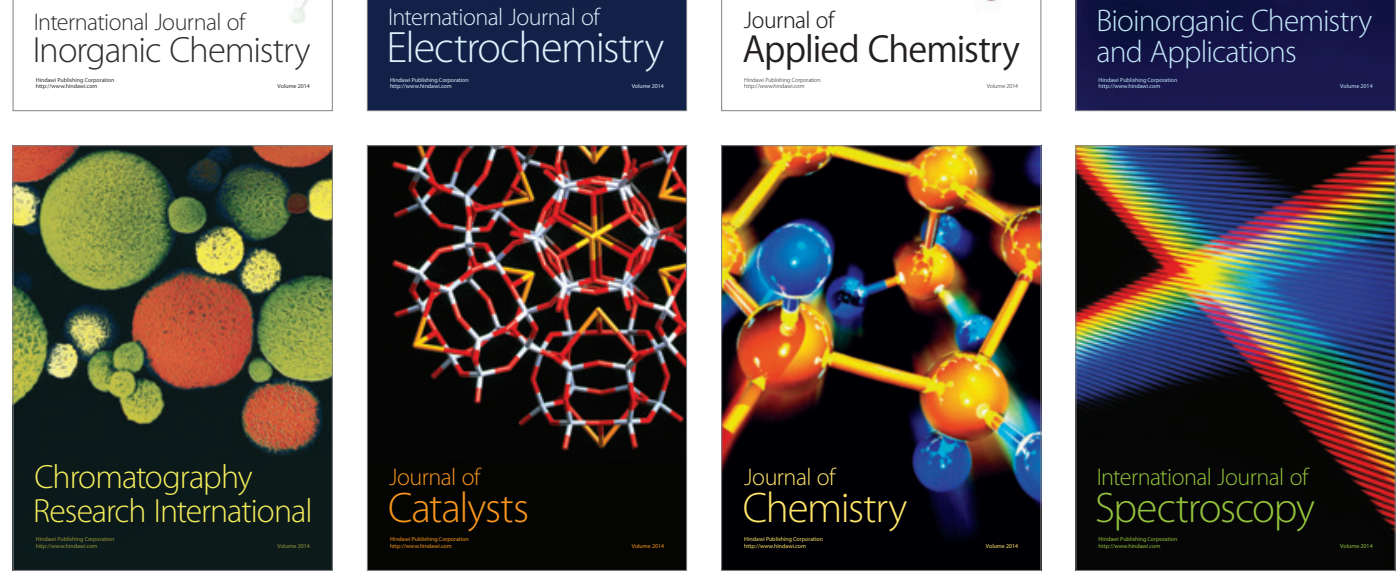